\title{
Contribution of Geo-electrical Soundings and Pedological Wells to the Estimation of the Tonnage of Laterite Gravels of the Northwestern Flank of Mount Bangou: Implication in Road Construction.
}

FOKO TAMBA Carlos ( $\square$ carlosfoko52@gmail.com )

University of Dschang: Universite de Dschang https://orcid.org/0000-0002-8241-0083

KENGNI Lucas

University of Dschang: Universite de Dschang

TEMATIO Paul

Université de Dschang: Universite de Dschang

Bertile llalie MANEFOUET

University of Dschang: Universite de Dschang

Jean Victor KENFACK

Université de Dschang: Universite de Dschang

\section{Research Article}

Keywords: mount Bangou, lateritic gravels, estimation, proven reserves of lateritic gravels, geophysical soundings, pedological wells

Posted Date: August 20th, 2021

DOI: https://doi.org/10.21203/rs.3.rs-825676/v1

License: (c) (i) This work is licensed under a Creative Commons Attribution 4.0 International License.

Read Full License 


\title{
CONTRIBUTION OF GEOELECTRICAL SOUNDINGS AND PEDOLOGICAL WELLS TO THE ESTIMATION OF THE TONNAGE OF LATERITE GRAVELS OF THE NORTHWESTERN FLANK OF MOUNT BANGOU: IMPLICATION IN ROAD CONSTRUCTION.
}

FOKO TAMBA Carlos ${ }^{a^{*}}$, KENGNI Lucas ${ }^{a}$, TEMATIO Paul ${ }^{\text {a }}$, MANEFOUET Bertile Ilalie ${ }^{\text {a }}$, KENFACK Jean Victor ${ }^{\mathrm{a}}$

${ }^{a}$ University of Dschang, Faculty of Science, Department of Earth Science, P.O. Box 67 Dschang, Cameroon.

* Corresponding author. E-mail address: carlosfoko52@ gmail.com (FOKO TAMBA Carlos).

\begin{abstract}
The increasing demands on lateritic gravels in road construction nowadays make it necessary to quantify the available resources that can be used in road construction. The aim of this study is to estimate the tonnage and to valorize the lateritic gravels of the North flank of Mount Bangou (West, Cameroon) in road construction. Interpretation of 48 vertical electrical soundings coupled with 20 pedological wells from 05 lateritic gravel sites was carried out to determine the thickness of the gravelly horizon. The thickness of the gravelly horizon obtained from the geo-electrical soundings is the highest ( 8.88 to $12.45 \mathrm{~m}$ ) compared to that obtained from the pedological wells $(1.23$ to $1.98 \mathrm{~m})$ and thus shows the inadequacy of the pedological wells for the determination of the thickness of the lateritic gravels. Thus, the electrical resistivity method is appropriate to estimate the thickness of the gravelly horizon. The lateritic gravels studied are characterized by the electrical resistivity curves of type K, HK, Q, QH, $\mathrm{KQ}, \mathrm{HKH}, \mathrm{H}$ and $\mathrm{KH}$. The medium ( 8 to $36 \mathrm{~m}$ ) and thick (13 to $44 \mathrm{~m}$ ) zones are areas of high potential lateritic gravels. The proven reserves of lateritic gravels at the Chenye, Sekakouo, Bamendjou 1, Bamendjou 2 and Bangam sites are respectively $3479003 \mathrm{t}, 1389522 \mathrm{t}, 5002505 \mathrm{t}, 839455 \mathrm{t}$ and $2663105 \mathrm{t}$ and can build respectively $539298 \mathrm{~m} ; 226167 \mathrm{~m} ; 131574 \mathrm{~m} ; 778314 \mathrm{~m}$ and $401068 \mathrm{~m}$ of road, either as a form layer or sub-base.
\end{abstract}

Keywords: mount Bangou, lateritic gravels, estimation, proven reserves of lateritic gravels, geophysical soundings, pedological wells

\section{Introduction}

The communication ways in general and the road infrastructure in particular are an important and unavoidable factor for the economic, cultural and social development of a country or a continent (Combere, 2008; Onana et al., 2015). In countries where a particular emphasis is placed on the development of various infrastructures, a considerable increase in the use of the soil resource is increasingly noticed. The majority of roads in the tropics are in concretionary lateritic soils (Maignien, 1966). Because of the abundance of lateritic gravels in tropical countries, their low exploitation costs and their much easier exploitation than certain crystalline formations (CEBTP, 1980; Sikali and Mir-emirati, 1986; Meissa, 1993; Bagarre, 1990), they are of obvious interest in road construction. They constitute almost $100 \%$ of the sub-base layers and 60 to $70 \%$ of the base layers of roadways in the intertropical zone, more specifically in developing countries (Tockol, 1993).

Laterites show great typological diversity in the intertropical zone in general and in Cameroon in particular. Thus, lateritic gravels; lateritic breastplates; lateritic carapaces; and lateritic fines are encountered in Cameroon (Sikali and Mir Emérati, 1986; Mbumbia et al., 2000; Hyoumbi Tchumgouelieu et al., 2018) and cover about 70\% of the area of Cameroon (Sikali and Mir Emérati, 1986). Previous work has been done by Manefouet (2016) on the alterological and geotechnical characterization of lateritic clays and gravels of the lower zone of the southern slope of the Bambouto Mountains, by Sikali and Mir-emarati, (1986); Ekodeck, 1984; Nzabakurikiza et al. (2012); Onana et al. (2015); Takala et al. (2018); Hyoumbi Tchungouelieu et al. (2017), Ngo'o Ze et al. (2019) on their use in road technique. Thus, depending on their geotechnical properties closely related to their origins (parent rocks), altitude, vegetation and climate, they are used either as base layer, sub-base layer or as form layer (Sikali and Mir Emérati, 1986). Nevertheless, the systematic use of laterites as construction materials is beginning to make them a scarce resource in some parts of Africa (Bohi, 2008). This "scarce resource" status has resulted in the necessity of quantifying the available and usable resources in civil engineering construction (Bohi, 2008), given the necessity for developing countries to build an accurate database of their soil resources. Similarly, a serene and equitable exploitation of lateritic gravels requires knowledge of the resource and its quantity. In addition to the geotechnical characteristics and the cost of exploitation of lateritic gravels, the knowledge of their tonnage is crucial to their exploitation.

The most commonly used method of estimating geo-material tonnage is that which takes into account the surface area, specific gravity and thickness of the geo-material. However, the spatial heterogeneity and great thickness of lateritic soils, as well as the presence of indurated levels (Tardy, 1997) do not facilitate the realization of pedological wells until the wall of the lower gravelly level. In such a context, geo-electrical soundings, nonintrusive and capable of simultaneously investigating a large volume of soil (Rey, 2005) coupled with pedological wells constitute an interesting alternative. Their rapid implementation and relatively low cost can allow a more reliable determination of the thickness of the soil layers, and eventually a more reliable estimation of the tonnage of lateritic gravels. This study aims to determine the tonnage of lateritic gravels on the northern flank of Mount Bangou and their use in road construction using an approach based on geophysical surveys coupled with soil wells. 


\section{Geographic and geological setting}

The northern flank of Mount Bangou is located in the West Cameroon region, straddling the Kong-Khi and Highlands departments. It is located in the localities of Sekakouo, Chenye, Bamendjou 1, Bamendjou 2 and Bangam. Mount Bangou, built during the Eocene, is the oldest dated volcano in the Cameroon Volcanic Line (CVL) (Fosso et al. 2005). It is located between $5^{\circ} 28^{\prime} 1.23^{\prime \prime} \mathrm{N}$ and $5^{\circ} 15^{\prime} 51.83^{\prime \prime} \mathrm{N}$ latitude and between $10^{\circ} 31^{\prime} 33.6^{\prime \prime}$ and $10^{\circ} 14^{\prime} 14.25^{\prime \prime}$ E longitude and belongs to the West Cameroon Highlands. It covers an area of $354 \mathrm{~km}^{2}$ (Fig 1). Altitudes in the area vary from $990 \mathrm{~m}$ to $2045 \mathrm{~m}$ with an average of $1518 \mathrm{~m}$. The climate is humid tropical, tempered by altitude (Nono et al., 2009) and sub-equatorial (Olivry, 1986) with an average annual rainfall of 1 $741 \mathrm{~mm}$ and $1674 \mathrm{~mm}$, the temperature gradient varying from $20.3^{\circ} \mathrm{C}$ to $23,0^{\circ} \mathrm{C}$ (Sighomnou, 2004; Nono and al., 2009) and from $20,0^{\circ} \mathrm{C}$ to $23.5^{\circ} \mathrm{C}$ respectively for the sites in the Kong-khi department and those in the Highlands.

\section{Insert figure 1}

Study area is marked by volcanic, plutonic and metamorphic rocks. The volcanic rocks are constituted by Aphiric basalts, Tufs, sub-aphyric basalts, porphyroid basalts, rhyolites, quartz-trachyte and rhyolites, rhyolites aegirine more or less arfvedsonite and plutonic rocks as porphyroid granite and syntectonic granite, granite with amphibole and/or biotite, granite with aegirine and/or eckermanite arfvedsonite, undifferentiated granito-gneissic, syenodiorite and Quartz-syenodiorite. The metamorphic rocks consist of orthogneiss with mega feldspar, orthogneiss at medium grain and undifferentiated metamorphic gneiss (Fosso et al., 2005; Kuepou et al., 2006; Nono et al., 2009; Nkwekam et al., 2010) (ref. Fig 1). Extensive weathering of the rocks in this region has resulted in huge lateritic soil volumes. The highlands of western Cameroon are occupied by red and brown ferralitic soils, hydromorphic soils and soils that are not very advanced (Segalen 1965). The lateritic gravels of the northern flank of Mount Bangou are developed on aphyric basalts (Fig 1).

\section{Materials and methods}

\subsection{Field data acquisition}

The field sampling data are shown in Figure 2. The field campaigns consisted of prospecting the gravelly formations in the study area and selecting representative sites. The sites of Sekakouo, Chenye, Bamendjou 1, Bamendjou 2 and Bangam were selected for this work. Altitude levels guided the selection of representative sites, as many studies have shown the influence of altitude levels on soil distribution in the landscape (Leumbe Leumbe et al. 2005, Tematio, 2005, Hyoumbi Tchumgouelieu et al., 2017, Hyoumbi Tchumgouelieu et al., 2018). The fieldwork also consisted of the implementation of pedological wells and the collection of samples for physicalmechanical analyses. The pedological wells were implanted in reference to the toposequential method. They were located at the top, on the slope and at the foot of the gravelly zone of each site. Twenty pedological wells were made on all five sites studied. Soil profiles were described through the soil pits with reference to the Maignien (1980) method of morpho-structural soil description in the field. The Munsel code was used to determine the color of the soil volumes in the soil profiles. The perimeter coordinates of the gravelly zone at each gravel site were surveyed in the field with a Garmin 30x GPS terminal (global positioning system) via the surface tracing option of the terminal.

\subsection{Geo-electrical data and interpretation}

Geo-electrical data were acquired at the separate lateritic gravel sites (Fig 2). The Vertical electrical soundings of the Schlumberger type were carried out with the Lipman 4point light 10W resistivity meter at the node of each previously established mesh. The mesh was established beforehand on each gravel site following a very specific spacing in order to cover the entire site studied (Fig. 2). Forty-eight vertical electrical soundings (VES) were carried out on all five sites.

\section{Insert figure 2}

The electrical device used in the geophysical campaign is that of Schlumberger. The center of the device, called the tracing point or station, remains fixed (Fig. 3), and the current injection electrodes (A and B) are progressively moved away from the center of the device (station). The electrodes $\mathrm{M}$ and $\mathrm{N}$ remain fixed for a series of measurements corresponding to a certain number of separations of $\mathrm{A}$ and $\mathrm{B}$, and then are moved apart generally taking into account the relationship $4<\mathrm{AB} / \mathrm{MN}<20$. Since the current is known, the potential can be measured and the apparent resistivity can be calculated using equation (1).

$$
\boldsymbol{\rho} \mathbf{a}=\frac{\pi \Delta \mathbf{V}}{I}\left[\frac{\left(\frac{A B}{2}\right)^{2}-\left(\frac{M M}{2}\right)^{2}}{M N}\right]
$$

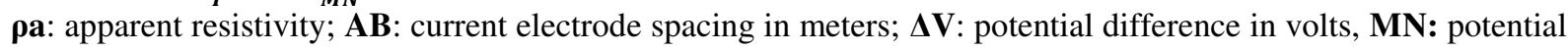
electrode spacing in meters; $\mathbf{I}$ : current intensity in Ampere; $\boldsymbol{\pi}=22 / 7$ 
In these analyses, the maximum extent of $\mathrm{AB} / 2$ was $100 \mathrm{~m}$. The electrical method aims to determine the physico-electrical properties of the soil or subsoil (conductivity, resistivity and resistance) through the electrical soundings, which led to the evaluation of the layout of the ground layers and the determination of the thickness of the ground layers.

Insert figure 3

The electrical resistivity curves were interpreted automatically using geoelectrical joint inversion software (jointem). These inversions were used to average the apparent resistivities of each geoelectrical sounding point to determine the average thickness of the gravelly levels.

\subsection{Tonnage estimation}

The tonnage of each lateritic gravel site was evaluated by taking into account the average thickness of the gravelly mineral level, the total surface area of the gravelly zone, and the specific weight of the lateritic gravel at each site studied. Twenty sampling wells were drilled at varying depths depending on the thickness of the gravelly mineral level (B-horizon). The total area of the gravelly zone at each site was determined using Global Mapper software, after surveying the GPS coordinates of their perimeters in the field. The 1-D inversions of the VES were used to establish the geo-electrical sections and to determine the thicknesses of the gravelly mineral level (gravel) at the study sites. Thickness values from the 1-D inversions were corroborated with thicknesses from the soil wells. The product of the volume by the specific gravity yields the tonnage of the material investigated (Kouakou kouamé et al. 2017). The specific gravity was determined in accordance with the NF P94-054 standard. Thus knowing the total surface of each gravelly area, the average thickness of the gravelly mineral level and their specific gravity, the tonnage of lateritic gravels of each site was determined through equation 2 .

$\mathbf{T}=\mathbf{A} * \mathbf{E} * \boldsymbol{\gamma} \mathbf{s}$

$\mathbf{T}$ is tonnage in $\mathbf{t} ; \mathbf{A}$ is total area in $\mathbf{m}^{2} ; \mathbf{E}$ is thickness of gravelly level in $\mathbf{m}, \gamma \mathbf{s}$ is specific gravity in $\mathbf{t} / \mathbf{m}^{\mathbf{3}}$.

\subsection{Quantification in pavement layers}

The technical aspect, the economic aspect and the availability of the deposits usable in pavement layer orient the choice of the type of pavement structure. Moreover, the knowledge of the tonnage of lateritic gravels usable is decisive to their exploitability. It also allows better planning of the backfilling or reprofiling of roads. The thickness of the form layer, the sub-base layer and the base layer is generally about $30 \mathrm{~cm}$ (CEBTP, 1984). The structure of a pavement is more or less similar to a three-dimensional geometric shape. In rural areas, the average width of the roadway ways is $2 * 3.50 \mathrm{~m}$, and the shoulders are generally $2 * 2 \mathrm{~m}$ according to CEBTP (1984). Thus, the total width of a pavement layer is equivalent to $11.5 \mathrm{~m}$. According to Sikali and Mir-emirati (1986), one $\mathrm{m}^{2}$ of borrow material corresponds to about $0.75 \mathrm{~m}^{3}$ compacted in a pavement. The volume of lateritic gravel for $1 \mathrm{~km}$ of pavement was calculated with reference to equation (3).

$$
\begin{aligned}
& \mathrm{V}(1 \mathrm{~km})=\mathrm{L} \mathrm{Xl} \mathbf{l} \times \mathbf{h} \\
& Q=\frac{1000 \mathrm{~m} * A * E}{0.75(\mathrm{~L} * \mathrm{l} * \mathrm{~h})}
\end{aligned}
$$

$\mathbf{L} * \mathbf{I} \mathbf{h}=$ volume of a pavement layer, $\mathbf{L}$ is the length, $\mathbf{l}$ is the width and $\mathbf{h}$ is the height of the pavement layer concerned, $\mathbf{A}$ is the total area in $\mathbf{m}^{\mathbf{2}} ; \mathbf{E}$ is the thickness of the gravelly level in $\mathbf{m}, \gamma \mathbf{s}$ is the specific weight in $\mathbf{t} / \mathbf{m}^{\mathbf{3}}$, $\mathbf{Q}$ is the number of meter of road.

\section{Results}

4.1 Thickness of the gravelly lateritic level from the pedological wells

Twenty manual pedological wells were made at all five study sites. Table 1 summarizes the thickness values of the gravelly mineral level obtained from the pedological wells of the studied sites. Figure 4 shows the typical profiles observed on the different lateritic gravel sites studied.

The soil profile of the northern flank of Mount Bangou includes three (03) pedological levels (Fig. 4). They are of the ABC type. From top to bottom, the first level $(10$ to $86 \mathrm{~cm})$ corresponds to the light red organomineral level and is a fine pedoturbated soil with a silty, silty-clay and silty-sandy texture. The structure is lumpy and contains many rootlets.

The second level $(72$ to $387 \mathrm{~cm}$ ) is the gravelly mineral level with a predominantly light red, silty-clay, silty-sandy, silty, silty-sandy-clay and silty-sandy fine soil for the Sekakouo, Chenye, Bamendjou 1, Bamendjou 2 and Bangam soil profiles respectively. The structure is predominantly gravelly and contains abundant millimeter to multi-centimeter sized gravel (20-73\%).

The third horizon is the clay mineral horizon with a clay texture and polyhedral structure. However, the gravelly mineral horizon outcrops in some localities.

Insert figure 3 
Sekakouo site: Five pedological wells were drilled at this site: three wells were drilled on the slope, one well at the foot of the gravelly zone and one well at the top. The thickness of the gravelly mineral level at the Sekakouo site varied from 0.73 to $2.40 \mathrm{~m}$. The highest value corresponds to well CP14 at the top of the gravelly zone and the lowest to well $\mathrm{CP} 11$ at the bottom of the gravelly zone. The mean value of the thickness of the gravelly mineral level for these five wells is $1.23 \mathrm{~m}$ with a standard deviation of 0.69 . The total area of the gravelly zone is 143509 $\mathrm{m}^{2}$.

Chenye Site: Five soil wells were drilled at this site: two wells were drilled on the slope, two wells at the base of the gravelly zone, and one well at the top. Thickness values of the gravelly mineral level at the Chenye site range from 0.50 to $2.95 \mathrm{~m}$. The highest value corresponds to well CP34 at the top of the gravelly zone and the lowest to well CP31 at the bottom of the gravelly zone. The mean value of the thickness of the gravelly mineral level for these five wells is $1.45 \mathrm{~m}$ with a standard deviation of 0.97 . The total area of the gravelly zone is $51786 \mathrm{~m}^{2}$.

Bamendjou 1 site: Three pedological wells were drilled at this site: one well was drilled on the slope, another well at the foot of the gravelly zone, and one well at the top. The thickness of the gravelly mineral level at the Bamendjou 1 site varies from 0.97 to $2.98 \mathrm{~m}$. The highest value corresponds to well CP61 at the top of the gravelly zone and the lowest to well CP62 at the bottom of the gravelly zone. The average value of the thickness of the gravelly mineral level for the five soil wells is $1.93 \mathrm{~m}$ with a standard deviation of 1.02 . The total surface area of the gravelly zone is $16126 \mathrm{~m}^{2}$.

Bamendjou 2 site: Four soil wells were drilled at this site: two wells were drilled on the slope, one well at the foot of the gravelly area, and one well at the top. The thicknesses of the gravelly mineral level at the Bamendjou 2 site vary from 0.27 to $5.07 \mathrm{~m}$. The highest value corresponds to well CP73 at the top of the gravelly zone and the lowest to well CP71 at the bottom of the gravelly zone. The mean value for these five wells is $3.285 \mathrm{~m}$ with a standard deviation of 2.08. The mean value for these five wells is $1.23 \mathrm{~m}$ for a standard deviation of 0.69 . The total area of the gravelly zone is $157462 \mathrm{~m}^{2}$.

Bangam Site: Three pedologic wells were drilled at this site: one well was drilled on the slope, two wells were drilled at the foot of the gravelly zone, and one well was drilled at the top. Thickness values of the gravelly mineral level at the Bangam site range from 0.08 to $4.02 \mathrm{~m}$. The highest value corresponds to well CP83 at the top of the gravelly zone and the lowest to well CP82 at the bottom of the gravelly zone. The mean value for these five wells is $2.01 \mathrm{~m}$ with a standard deviation of 1.76 . The total area of the gravelly zone is $78519 \mathrm{~m}^{2}$.

Insert table 1

\subsection{1-D Inversion}

Modelling of data from forty-eight (48) VES carried out on all five sites shows the existence of eight (08) models of electrical resistivity curves (K, HK, Q, QH, KQ, HKH, H and KH) (Fig 5 to Fig 12). This typological multiplicity of resistivity curves confirms the structural heterogeneity of the lateritic soils of the North Slope of Mount Bangou. The SEV curves were compared with the soil profiles and the geological history of the region in order to better reconstruct the litho-pedological sections. The resistivities of the gravelly level range from 100 to $10,000 \Omega . \mathrm{m}$

Insert figure 5

Insert figure 6

Insert figure 7

Insert figure 8

Insert figure 9

Insert figure 10 


\section{Insert figure 12}

Sekakouo site: The one-dimensional inversion (1-D) of the vertical electrical soundings (VES) made at the Sekakouo site shows the existence of electrical resistivity curves of type K, Q, QH, HK and H. The QH and H type resistivity curves predominate and the $\mathrm{K}$ type curves are the least common at this site. The number of layers varies from 4 to 5. The litho-pedological section of the VES at the Sekakouo site consists of lateritic gravel, lateritic breastplate, silts, clays, groundwater and granite-gneissic basement (Fig 13). Thicknesses of the gravelly mineral level vary from 1.45 to $18.66 \mathrm{~m}$ with a mean of $8.88 \mathrm{~m}$ and a standard deviation of 5.33 (Table 2). The highest thickness is obtained at the VES1 Sounding Point and the least at the VES4 Sounding Point.

\section{Insert figure 13}

Insert table 2

Chenye site: The Chenye site is characterized by KH, Q, QH, HK and H type electrical resistivity curves. The $\mathrm{H}$ and KH type curves are the least encountered at this site. The number of layers varies from 4 to 5 . The organomineral horizon, gravel, lateritic breastplate and clay characterize the litho-pedology of the Bamendjou 1 site. The average thickness of the gravelly mineral level is $10.32 \mathrm{~m}$ with a standard deviation of 3.80 . They vary from 5.32 to $15.60 \mathrm{~m}$ (Table 3). The highest thickness is obtained at the VES1 sounding point and the lowest at the VES3 sounding point (Fig. 14).

Insert figure 14

Insert table 3

Bamendjou 1 site: The Bamendjou 1 site is characterized by K, Q and HK electrical resistivity curves. The number of layers varies from 4 to 5. Gravel, lateritic breastplate, clay and sound rock characterize the litho-pedology of the Bamendjou 1 site. The average thickness of the gravelly mineral level is $11.68 \mathrm{~m}$ with a standard deviation of 8.01. They vary from 0.39 to $23.52 \mathrm{~m}$ (Table 4). The highest thickness is obtained at the VES3 sounding point and the lowest at the VES1 sounding point (Fig. 15).

Insert figure 15

Insert table 5

Bamendjou 2 site: The Bamendjou 2 site is characterized by $\mathrm{K}, \mathrm{HKH}$ and $\mathrm{H}$ type electrical curves. The H-type electrical curves predominate. This site is the only one to admit HKH type electrical resistivity curves. Overall, the number of layers is 4. The litho-pedological section of the VES at the Bamendjou 2 site consists of gravel, lateritic breastplate, clay, sound rock, basalt and granite-gneissic basement. The thicknesses of the gravelly mineral level vary from 0.8 to $47.38 \mathrm{~m}$. The highest thickness is obtained at the VES1 sounding point and the lowest is obtained at the VES 3 sounding point (Fig 16). The average thickness is $19.28 \mathrm{~m}$ with a standard deviation of 20.28 (Table 5). 
Insert figure 16

Insert table 5

Bangam site: The electrical resistivity curves of type $\mathrm{KH}, \mathrm{Q}, \mathrm{KQ}, \mathrm{HK}$ and $\mathrm{H}$ characterize the Bangam site. This site is dominated by Q-type electrical resistivity curves and KQ-type curves are the least encountered. The number of layers varies from 4 to 5. The litho-pedological section of the VES at the Bangam site consists of gravel, lateritic breastplate, sound rock fragments, sound rock, clay, groundwater, basalt and granite-gneissic basement. The thicknesses of the gravelly mineral level vary from 1.49 to $26.64 \mathrm{~m}$. The highest thickness is obtained at test point VES2 and the lowest at test point VES7 (Fig. 17). The average thickness is $12.07 \mathrm{~m}$ with a standard deviation of 6.61 (Table 6).

Insert figure 17

Insert table 6

\subsection{Thickness maps of the gravelly lateritic horizon}

The thickness maps of the gravelly mineral horizon were made solely from the thickness data from the geoelectrical surveys. These maps show three thickness zones: thin zone, medium zone and thick zone.

Sekakouo site: Figure 18(a) shows the thickness distribution of the gravelly level at the Sekakouo site. The thin zones are observed to the NW and NE of the gravelly zone and have thicknesses between 1 and $8 \mathrm{~m}$. The medium thickness zones ( 8 to $13 \mathrm{~m}$ ) are the most encountered and individualize a band that extends from the East to the North and SW. The thicker zones cover the SE and have thicknesses between 13 and $19 \mathrm{~m}$.

Chenye site: The thickness of the lateritic gravels at the Chenye site is shown in Figure 18(b). The thin zones occupy the east and west of the gravelly zone and range from 5 to $10 \mathrm{~m}$ thick. The medium thickness zones $(10$ to $13 \mathrm{~m})$ are the most represented and are encountered in the north, center, and part of the south of the gravelly zone. The thicker zones (13 $\mathrm{m}$ to $16 \mathrm{~m}$ ) are the least encountered and occupy part of the northern gravelly zone (Fig 18c).

Bamendjou 1 site: At Bamendjou 1, the thin zone individualizes a band in the NW part of the study area. Thin formations in the form of pockets are also observed to the south and SE of the gravelly zone. Thicknesses of the shallow zone range from 3 to $13 \mathrm{~m}$. The medium thickness zones (13 to $20 \mathrm{~m}$ ) are the most encountered and occupy part of the SW and part of the SE. The thicker zones are observed to the NNE and SW and have thicknesses that vary from 20 to $27 \mathrm{~m}$ (Fig. 18d).

Bamendjou 2 site: Figure 18(e) shows the thickness distribution of the gravelly level at the Bamendjou 2 site. The thin areas are the most encountered and are observed at NS of the gravelly zone and have thicknesses between 9 and $24 \mathrm{~m}$. The medium thickness zones ( 24 to $36 \mathrm{~m}$ ) occupy the NW of the gravelly zone. The thicker zones are the least encountered and are observed to the NNW. Their thicknesses vary from 36 to $44 \mathrm{~m}$.

Bangam site: The thicknesses of the lateritic gravels at the Bangam site are shown in Figure 18(f). The thin domains occupy the SSW, SE and NNE of the gravelly zone and range in thickness from 1 to $12 \mathrm{~m}$. The medium thickness domains (12 to $19 \mathrm{~m}$ ) are the most represented and are encountered in the central and NW of the gravelly zone. The thicker zones $(19 \mathrm{~m}$ to $27 \mathrm{~m}$ ) are the least encountered and occupy the western part of the gravelly zone.

Insert figure 18

\subsection{Specific gravity}

The specific gravity $(\gamma \mathrm{s})$ values obtained range from $2.60 \mathrm{t} / \mathrm{m} 3$ to $2.81 \mathrm{t} / \mathrm{m} 3$. The values $2.73 \mathrm{t} / \mathrm{m} 3 ; 2.60$ $\mathrm{t} / \mathrm{m} 3 ; 2.72 \mathrm{t} / \mathrm{m} 3 ; 2.70 \mathrm{t} / \mathrm{m} 3$ and $2.81 \mathrm{t} / \mathrm{m} 3$ are noted for the SEK; CHE; BAM1; BAM2 and BAN samples respectively (Table 7). The mean value for the 05 sites is $2.71 \mathrm{t} / \mathrm{m} 3$ with a standard deviation of 0.08 .

\subsection{Estimated tonnage of lateritic gravels studied}

The calculation of gravelly volume involves the thickness of the gravelly mineral level and the total surface area of the gravelly zone at the site. The thickness of the gravelly level at the Sekakouo, Chenye, Bamendjou 1, Bamendjou 2 and Bangam sites was determined from the interpretation of the geo-electrical soundings and the pedological wells. Thus, the product of the volume by the specific gravity provides the tonnage of the material sought (Kouakou Kouamé et al. 2017). 


\subsubsection{Site tonnage from determined pedological well thicknesses}

The values $481889 \mathrm{t} ; 195233 \mathrm{t} ; 822330 \mathrm{t} ; 143030 \mathrm{t}$ and 443483 are noted for the Sekakouo, Chenye, Bamendjou 1, Bamendjou 2 and Bangam sites respectively. The tonnage of the sites studied varies from 143030 $\mathrm{t}$ (Bamendjou 2 site) to $822330 \mathrm{t}$ (Bamendjou 1 site), for an average value of $417193 \mathrm{t}$ (Table 7).

4.5.2 Tonnage of the sites studied from the thicknesses determined from the geoelectric soundings.

Table 7 summarizes the specific gravity, gravelly mineral level thickness, gravelly area, volume, and gravelly tonnage by study site. Overall, the tonnage of the study sites ranges from 839455 t to 5002505 . The highest value corresponds to the Bamendjou 1 site and the lowest value corresponds to the Sekakouo site. The values of 3479003 t; 1389522 t; 5002505 t; 839455 and 2663105 are noted for the Sekakouo, Chenye, Bamendjou 1, Bamendjou 2 and Bangam sites respectively. The average value for the five sites is $2674718 \mathrm{t}$.

\section{Insert table 7}

\section{Assessment of the volume of lateritic borrow in pavement layers}

According to previous work by Foko Tamba (2021), the heterogeneous lateritic gravels of the northern flank of Mount Bangou are gravels and silty or clayey sands, and silty soils of subgroups A-2-7 and A-4 respectively according to the HRB classification; and silty gravels according to the LCPC classification. They can be used naturally in pavement layers, in particular in subgrades for all traffic classes. They can also be used in the sub-base for low traffic levels from T1 to T3, with the exception of lateritic gravels from the Chenye and Sekakouo sites (CEBTP, 1984; Sikali and Mir-emarati, 1986). Because of the inadequacy of soil wells for determining the thickness of lateritic gravels, the evaluation of the volume of lateritic borrow studied in pavement layers took into account only the quantities of lateritic gravels determined from the geophysical data.

\subsection{Evaluation in the form layer}

In road construction, the installation of a form layer is only necessary when the platform or the upper part of the excavation does not have sufficient bearing capacity. Generally, the form layer is carried out in the aim of constructing the roadway on a homogeneous platform of good quality. The thickness of the form layer is generally equal to about $30 \mathrm{~cm}$ (CEBTP, 1984). Thus, the structure of a pavement is more or less equivalent to a threedimensional geometric shape. In rural areas, pavements generally have an average width of $7.50 \mathrm{~m}$ plus shoulders of $1.5 \mathrm{~m} * 2$. The volume of lateritic gravel for $1 \mathrm{~km}$ of roadway was calculated with reference to equation (5).

$\mathrm{V}(\mathbf{1} \mathbf{~ k m})=\mathbf{L} \times \mathbf{l} \times \mathbf{h}$

$\mathbf{L}$ is the length, $\mathbf{I}$ is the width and $\mathbf{h}$ is the height.

A.N: For $\mathbf{L}=1000 \mathrm{~m} ; \mathbf{l}=10.5 \mathrm{~m} ; \mathbf{h}=0.3 \mathrm{~m}$.

We have:

$\mathrm{V}(1 \mathrm{~km})=1000 \times 10.5 \times 0.3$

$\mathrm{V}(1 \mathrm{~km})=3150 \mathrm{~m}^{3}$

Sikali and Mir-emarati, (1983) report that $1 \mathrm{~m} 2$ of lateritic gravelly borrow material corresponds to about $0.75 \mathrm{~m} 3$, compacted into a pavement layer. In this context, for $1000 \mathrm{~m}$ of road length, approximately $2363 \mathrm{~m} 3 \mathrm{of}$ material will be used. As a reference, at CEBTP, the gravel from the Sekakouo, Chenye, Bamendjou 1, Bamendjou 2 and Bangam sites can be used in a form layer.

Sekakouo site: The Sekakouo site shows a proven reserve of $1274360 \mathrm{~m}^{3}$, or a tonnage of $3479003 \mathrm{t}$ for an area of $143509 \mathrm{~m}^{2}$. Thus, $1274360 \mathrm{~m} 3$ can build about $539298 \mathrm{~m}$ of road in form layer, either $539.298 \mathrm{~km}$.

Chenye site: The proven reserve of the Chenye site is $534432 \mathrm{~m} 3$, or a tonnage of $1389522 \mathrm{t}$ for an area of 51 $786 \mathrm{~m}^{2}$. Therefore, $534432 \mathrm{~m}^{3}$ can build approximately $226167 \mathrm{~m}$ of road in form layer, either $226.167 \mathrm{~km}$.

Bamendjou 1 site: At Bamendjou 1, the proven reserve is $1839156 \mathrm{~m}^{3}$, or a tonnage of $5002505 \mathrm{t}$ for an area of $157462 \mathrm{~m}^{2}$. Thus, $1839156 \mathrm{~m}^{3}$ of lateritic gravels can build about $778,314 \mathrm{~m}$ of road in form layer, either $778.314 \mathrm{~km}$.

Bamendjou 2 site: The Bamendjou 1 site shows a proven reserve of $310909 \mathrm{~m}^{3}$, or a tonnage of $839,455 \mathrm{t}$ for an area of $78,519 \mathrm{~m}^{2}$. Therefore, $310,909 \mathrm{~m} 3$ can build about $131,574 \mathrm{~m}$ of road in form layer, either $131.574 \mathrm{~km}$.

Bangam site: The proven reserve of the Bangam site is $947724 \mathrm{~m} 3$, or a tonnage of $2663105 \mathrm{t}$ for an area of 78 $519 \mathrm{~m}^{2}$. Thus, $947724 \mathrm{~m}^{3}$ of lateritic gravels can build approximately $401068 \mathrm{~m}$ of road in form layer, either $401.068 \mathrm{~km}$.

\subsection{Evaluation in sub-base}

According to CEBTP (1984), the sub-base layer must have a maximum thickness of $25 \mathrm{~cm}$ and a minimum thickness of $10 \mathrm{~cm}$. With reference to equation (3), the volume of lateritic gravels for the construction of $1 \mathrm{~km}$ of pavement was calculated.

$$
\frac{\text { A.N: For } \mathbf{L}=1000 \mathrm{~m} ; \mathbf{l}=10.5 \mathrm{~m} ; \mathbf{h}=0.25 \mathrm{~m} .}{\mathbf{V}=\mathbf{1 0 0 0} \times \mathbf{1 0 . 5} \times \mathbf{0 . 2 5}}
$$




\section{$\mathrm{V}=2625 \mathrm{~m} 3$}

For $1000 \mathrm{~m}$ of road length, approximately $2625 \mathrm{~m} 3$ of gravelly lateritic materials will be used. In Cameroon, for a soil to be eligible as a sub-base, it must have a bearing capacity equal to or greater than $30 \%$, although a CBR of $25 \%$ can be tolerated for Tl traffic (Sikali and Mir-emarati, 1986). Thus, the gravelly lateritic materials of the Bamendjou 1, Bamendjou 2 and Bangam sites can be used as sub-base (CEBTP, 1984; Sikali and Mir-emarati, 1986).

According to Sikali and Mir-emarati, (1986) $1 \mathrm{~m}^{2}$ of borrowed lateritic gravelly material corresponds to about $0.75 \mathrm{~m} 3$ compacted in a pavement layer. Thus, $196875 \mathrm{~m}^{3}$ of lateritic gravel would construct $1 \mathrm{~km}$ of pavement.

Bamendjou 1 site: At Bamendjou 1, the proven reserve is $1839156 \mathrm{~m}^{3}$, or a tonnage of $5002505 \mathrm{t}$ for an area of $157462 \mathrm{~m}^{2}$. Thus, $1839156 \mathrm{~m} 3 \mathrm{can}$ build approximately $934174 \mathrm{~m}$ of road in sub-base, either $934.174 \mathrm{~km}$.

Bamendjou 2 site: The Bamendjou 1 site shows a proven reserve of $310909 \mathrm{~m} 3$, or a tonnage of $839455 \mathrm{t}$ for an area of $78519 \mathrm{~m}^{2}$. Therefore, $310909 \mathrm{~m} 3$ can build about $157,922 \mathrm{~m}$ of road in foundation layer, either 157.922 $\mathrm{km}$.

Bangam site: The proven reserve of the Bangam site is $947724 \mathrm{~m}^{3}$, or a tonnage of $2663105 \mathrm{t}$ for an area of 78 $519 \mathrm{~m}^{2}$. Thus, $947724 \mathrm{~m}^{3}$ can build about $481384 \mathrm{~m}$ of road in sub-base layer, either $481.384 \mathrm{~km}$.

\section{Discussions}

The pedological wells and the interpretation of the vertical electrical soundings revealed relatively thick gravelly mineral levels (weathering set) $(\sim 35 \mathrm{~m})$ compared to the organo-mineral horizon (pedoturbated set). This disproportion in thickness between the weathering and pedoturbated package is a typical feature of soils in hot and humid regions, such as ferralitic soils, where weathering is generally very intense (Chatelin, 1974; Bitom, 1988; Tardy, 1993; Leumbe Leumbe et al., 2005). The lateritic gravels on the northern flank of Mount Bangou are characterized by a multiplicity of electrical resistivity curve shapes (K, HK, Q, QH, KQ, HKH, H and KH). The shape of the curves obtained is similar to those identified in the volcanic zones of Cameroon by Ananfack Keleko et al, (2013) and in the crystalline zones of Cameroon by Njueya Kopa et al, (2016). This suggests that the shape of resistivity curves is influenced by topography, thickness, degree of weathering and presence or absence of fractures (Njueya Kopa et al, 2016) and most importantly by the arrangement of soil constituents and their spatial arrangement (Cousin et al, 2012) rather than by lithological nature. The analysis of pedological wells coupled with the VES shows that the structural heterogeneity of the terrain is responsible for the diversity of curve patterns. This observation is coherent with the observations of many authors (Rey, 2005; Buvat, 2012; Cousin et al., 2012 Tonang Zebaze et al., 2020). The electrical resistivities and thicknesses of the gravelly mineral level are highly variable from one point of the VES to another of the studied sites and would reflect also the structural heterogeneity of these materials. Tonang Zebaze et al (2020) also noted this structural heterogeneity in the Mbakaou soils of the Adamawa Plateau. This heterogeneity is attributed to variations in the nature and intensity of most processes involved in pedogenesis (Tabbagh et al., 2000; Hovhannissian et al., 2011). The resistivities of the studied gravels range from 130.00 to 9161.10 S.m and are in conformity with the abacuses of Palacky (1991) and Marescot (2006), and field observations. These resistivity values show that the gravels at the explored sites are more or less wetted by water. Analysis of the electrical resistivity curves coupled with the soil wells reveals information on both the variation in soil resistivity and the geometric characteristics of the different soil layers located between the surface and the depth of investigation. They are located at various depths. The thickness of the gravelly mineral horizon obtained from the geo-electrical soundings is the highest ( 8.88 to $12.45 \mathrm{~m}$ ) compared to that obtained from the pedological wells $(1.23$ to $1.98 \mathrm{~m})$. This shows the inadequacy of pedological wells in determining the thickness of lateritic gravels and this inadequacy would be related to the spatial heterogeneity, the great thickness of lateritic soils, as well as the presence of indurated levels (Tardy, 1997). The analysis of the thickness maps shows areas of low, medium and high thickness. The zones of medium and high thickness constitute zones of high potential lateritic gravels.

\section{Conclusion}

The estimation and valorization of the lateritic gravels of the northern flank of Mount Bangou (West Cameroon) in road construction was carried out on 05 sites by an approach based on geophysical soundings coupled with pedological wells. The soil profiles of this area are of ABC type. The interpretation of 48 vertical electrical soundings coupled with 20 pedological wells made it possible to determine the thickness of the gravelly mineral horizon. They are characterized by the electrical resistivity curves of type K, HK, Q, QH, KQ, HKH, H and $\mathrm{KH}$. It was established from this study that electrical resistivity methods electrical resistivity methods are appropriate for estimating the thickness of the gravelly mineral horizon. The medium and thicker zones are areas of high potential for lateritic gravelly material. The proven reserves of lateritic gravels at the Chenye, Sekakouo, Bamendjou 1, Bamendjou 2 and Bangam sites are 3479003 t; 1389522 t; 5002505 t; 839455 t and 2663105 $\mathrm{t}$ respectively. The lateritic gravels of the Chenye, Sekakouo, Bamendjou 1, Bamendjou 2 and Bangam sites can build about $539298 \mathrm{~m} ; 226167 \mathrm{~m} ; 131574 \mathrm{~m} ; 778314 \mathrm{~m}$ and $401068 \mathrm{~m}$ of road, either as a form layer or a sub- 
base. However, the lateritic gravels of the Chenye and Sekakouo sites are not used as sub-base. It is recommended that these lateritic gravels be mined from the thicker areas.

Acknowledgements

The authors would like to thank the various chiefdoms of the Kong-Khi district and the highlands for their hospitality during the field investigations.

References

Ananfack Keleko TD, Tadjou JMK, Tabod CT, Feumoe Sieyapdjie AN, Kenfack JV (2013) Groundwater investigation using Geoelectrical method: a case study of the Western Region of Cameroon. J Water Resource Protection 5:633 - 641. http://dx.doi.org/10.4236/jwarp.2013.56064

Bagarre E, (1990) Utilisation des graveleux latéritiques en technique routière. ISTED, 1-150

Bitom D (1988) Organisation et évolution d'une couverture ferralitique en zone tropicale humide (Cameroun). Genèse et transformation d'ensembles ferrugineux indurés profonds. Thèse Doct. Univ. Poitiers, 164 p.

Bohi Zondjé PB (2008) Caractérisation des sols latéritiques utilisés en construction routière : le cas de la région de l'agnéby (côte d'ivoire). Thèse doct. Ecole Nationale des Ponts et Chaussées, $121 \mathrm{p}$.

Buvat S (2012) Caractérisation de l'organisation spatiale de la couverture pédologique par mesure de la résistivité électrique. Universite pierre et marie curie, Th. Doct. Géophysique appliquée, $186 \mathrm{p}$.

Chatelin Y (1974) Les sols ferralitiques. Tome 3. L'altération. Init. Doc. Tech. ORSTOM, 144 p.

CEBTP (1984) Guide pratique de dimensionnement des chaussées pour les pays tropicaux. Centre d'expertise du bâtiment et des travaux publics, Saint-Rémy-lès-Chevreuse, $155 \mathrm{p}$.

Combere M (2008) Problématique du dimensionnement des chaussées souples au Burkina Faso. Mem. Maitr. Univ. Thies, $164 \mathrm{p}$

Coussin I, Besson A, Seger M, Giot G, Richard G, King D (2012) L'apport des methods géophysiques au service de la caractérisation de la fertilité des sols. Innovation Agronomiques 21, 13-29

Ekodeck GE (1984) L'altération des roches métamorphiques du Sud Cameroun et ses aspects géotechniques. $P h D$ thesis. Université de Grenoble I, Grenoble, $392 \mathrm{p}$

Fauchard C, Mériaux P (2004) Méthodes géophysiques et géotechniques pour le diagnostic des digues de protection contre les crues. Cemagref éditions, $124 \mathrm{p}$.

Fosso J, Ménard JJ, Bardintzeff JM, Wandji P, Tchoua FM, Bellon H (2005) Les laves du Mont Bangou : une première manifestation volcanique éocène, à affinité transitionnelle, de la Ligne du Cameroun. Comptes Rendus Geoscience 337: 315-325.

Hovhannissian C, Clermontc Z, Siltetchos Hammecker Z, Winiyakinateekul W, Suvannang N, Silvera X, Robainn H, Podwojewskl P (2011) Etude de la variabilité spatiale des sols et des processus d'interaction «sol-eau-plante-atmosphère» par des méthodes géophysiques dans des plantations d'hévéa en Thaïlande. 36èmes Journées Scientifiques du GFHN- 8 ème colloque GEOFCAN, 10 P.

Hyoumbi Tchungouelieu W, Wouatong ASL, Pizette P, Abriak NE, Medjo ER (2017) Assessment of laterite suitable for road construction in Bafang Area (West-Cameroon) based on physical properties, geoenvironmental factors and GIS software. JMEST 4, 6815-6829.

Hyoumbi Tchungouelieu W, Pizette P, Wouatong ASL, Abriak NE (2018) Mineralogical, chemical, geotechnical and mechanical investigations of Bafang lateritic fine soils formed on basalts (WestCameroon) for road embankment purpose. Earth Sci. Res. 7(2), 42-57

Kuepouo G (2006) Geology, petrology and geochemistry of the Tertiary Bana volcano-plutonic complex, west Cameroon, Central Africa. PhD Thesis. Kobe University, Kobe, 335 P.

Kouakou KA, Kouame LN, Djroh PS, Kouadio KL, Sombo BC (2017) Utilisation de la methode de resistivité electrique pour la recherche de carrieres granitiques et estimation du tonnage rocheux sur trois sites : ayame, bouake et ferkessedougou (cote d'ivoire). International Journal of Technical Research and Applications eISSN: 2320-8163, www.ijtra.com Volume 5, Issue 5, 40-46

Kwekam M, Liegeois JP, Njonfang E, Affaton P, Hartmann G, Tchoua F (2010) Nature, origin and significance of the Fomopéa Pan-African high-K calc-alkaline plutonic complex in the Central African fold belt (Cameroon). J. Afri. Earth Sci. 57 p.

Leumbe Leumbe $\mathbf{O}$ (2005) Etude de sols ferralitiques à caractères andiques sur trachytes en zone de montagne humide tropicale (Mont Bambouto - Ouest Cameroun). Étude et Gestion des Sols, Volume 12, 4, 332-360.

Lyon Associates (1971) Laterite and lateritic soils and other problem soils of Africa. Inc. Baltimore Maryland, USA Building and Road Institute, 64-140.

Maignien R (1966) Compte rendu de recherches sur les latérites. Office de la recherche scientifique et technique outre-mer, Paris. $164 \mathrm{P}$

Maignien R (1980) Manuel pour la description des sols sur le terrain. O.R.S.T.O.M-Paris, 145 p.

Manefouet BI (2016) Caractérisation altérologique et géotechnique des argiles et graveleux latéritiques de la zone basse du versant Sud des monts bambouto - traitements aux liants hydrauliques. PhD. Université de Yaoundé I, Yaoundé, 332 p. 
Marescot L (2006) Introduction à l'imagerie électrique du sous-sol. Bulletin de la société.

Mbumbia L, Mertens de Wilmars A, Tirlocq J (2000) Performance characteristics of lateritic soil bricks fired at low temperatures: a case study of Cameroon. Construc. Build. Mater. 14: 121-131.

Meissa F (1993) Note sur les matériaux latéritiques et quelques résultats sur les latérites du Sénégal, Extrait Thèse de Doctorat INPL Nancy-France.

Ngo'o Ze A, Onana VL, Ndzié Mvindi NTA, Ohandja NH, Medjo Eko R, Ekodeck EG (2019) Variability of geotechnical parameters of lateritic gravels overlying contrasted metamorphic rocks in a tropical humid area (Cameroon). Bull. Eng. Geol. Environ 78: 5531-5549, 21 p.

Njueya Kopa A, Kengni L, Fonteh Fru M, Kagou Dogmo A, Ntankouo NR, Nkouathio, DG, Tazo C (2016) Apport des Sondages Électriques Verticaux à la Localisation et la Caractérisation des Aquifères en zone Volcanique au Cameroun : Cas d'Ebone et ses Environs. European Journal of Scientific Research. 1(138), 54-65

Nono A, Wabo H, Taboué Youmbi G, Tella Fotso Ndekam N, Biaya Sélambé, Ekodeck, GE (2009) Influence de la nature lithologique et des structures géologiques sur la qualité et la dynamique des eaux souterraines dans les hauts plateaux de l'Ouest-Cameroun : cas de la localité de Bandjoun. Int. J. Biol. Chem. Sci 3(2), 218-239.

Nzabakurikiza A, Onana VL, Likiby B, Kamgang Kabeyene V, Priso Ndome Effoudou V, Ekodeck EG (2012) Diagnostic de l'utilité en géotechnique des graveleux latéritiques sur migmatites de l'Est Cameroun par le biais des méthodes chimico-minéralogiques. Rev Cames sér. A 12 (Suppl. 2), 28-33.

Onana VL, Nzabakurikiza A, Ndome Effoudou E, Likiby B, Kamgang Kabeyene V, Ekodeck EG (2015) Geotechnical, mechanical and geological characterization of lateritic gravels of Boumpial (Cameroon) used in road construction. J. Camer. Acad. Sci. vol. 12 No. 1, 1, 45-54.

Palacky GJ and West GF (1991) airborne electromagnetic methods, in Nabighian, M.N., (ed.), Electromagnetic Methods in Applied Geophysics, vol. 2: Society of Exploration Geophysicists, $811-879$.

Rey E (2005) Caractérisation des sols hétérogènes par des méthodes géophysique. Thèse de doctorat de l'université de Joseph Fourier-Grenoble I, 232 P.

Sighomnou D (2004) Analyse et redéfinition des régimes climatiques et hydrologiques du Cameroun : perspectives d'évolution des ressources en eau. Thèse d'Etat ès Sciences Naturelles, Option : Sciences de l'eau, Département des sciences de la terre Université de Yaoundé 1, Cameroon, 291 p.

Sikali F and Mir-emarati D (1986) Utilisation des latérites en technique routière au Cameroun. Rapport inédit LABOGENIE, 277-288.

Segalen (1965) Les sols du plateau bamiléké. Cah. O.R.S. T.O.M. série Pédologie Vol. Vn³.

Tabbagh A, Dabas M, Hesse A, Panissod C (2000) Soil resistivity: a non-invasive tool to map soil structure horizonation. Geoderma 97: 393-404.

Takala, B.H., Mbessa, M., 2018. Geotechnical characterization of the Bafoufam lateritic gravels (west Cameroon) for road construction purpose. Conf. of the Arabian journal of geosciences, 125-127.

Tardy, Y., 1993. Pétrologie des latérites et sols tropicaux. Masson (ed) 459 p.

Tardy, Y., 1997. Petrology of laterites and tropical soils. A. A. Balkema, Rotterdam, 408 P.

Tematio, P., 2005. Etude cartographique et pétrologique des sols a caractères ferralitiques et andosoliques dans les monts Bambouto (Ouest Cameroun) : influence de la lithologie et des facteurs du milieu sur la nature et la distribution des sols en région de montagne tropicale humide. Thèse Doctorat d'Etat, University of Yaoundé I, 242 p.

Tockol, I., 1993. Contribution à l'étude des graveleux latéritiques dans les pays du Sahel : cas des routes non revêtues. Thèse de M.Sc.A. (Génie civil). Université de Moncton. 207 p.

Tonang, Zebaze1 A., Njueya Kopa A., Kwekam M., Temgoua E., 2020. Assessment of Hydrogeoelectrical Characteristics of Crystalline Aquifers and Groundwaters Quality in Adamawa Plateau: Case of Mbakaou (Adamawa - Cameroon). Environmental and Earth Sciences Research Journal Vol. 7, No. 4, 153-163. http://iieta.org/journals/eesr 


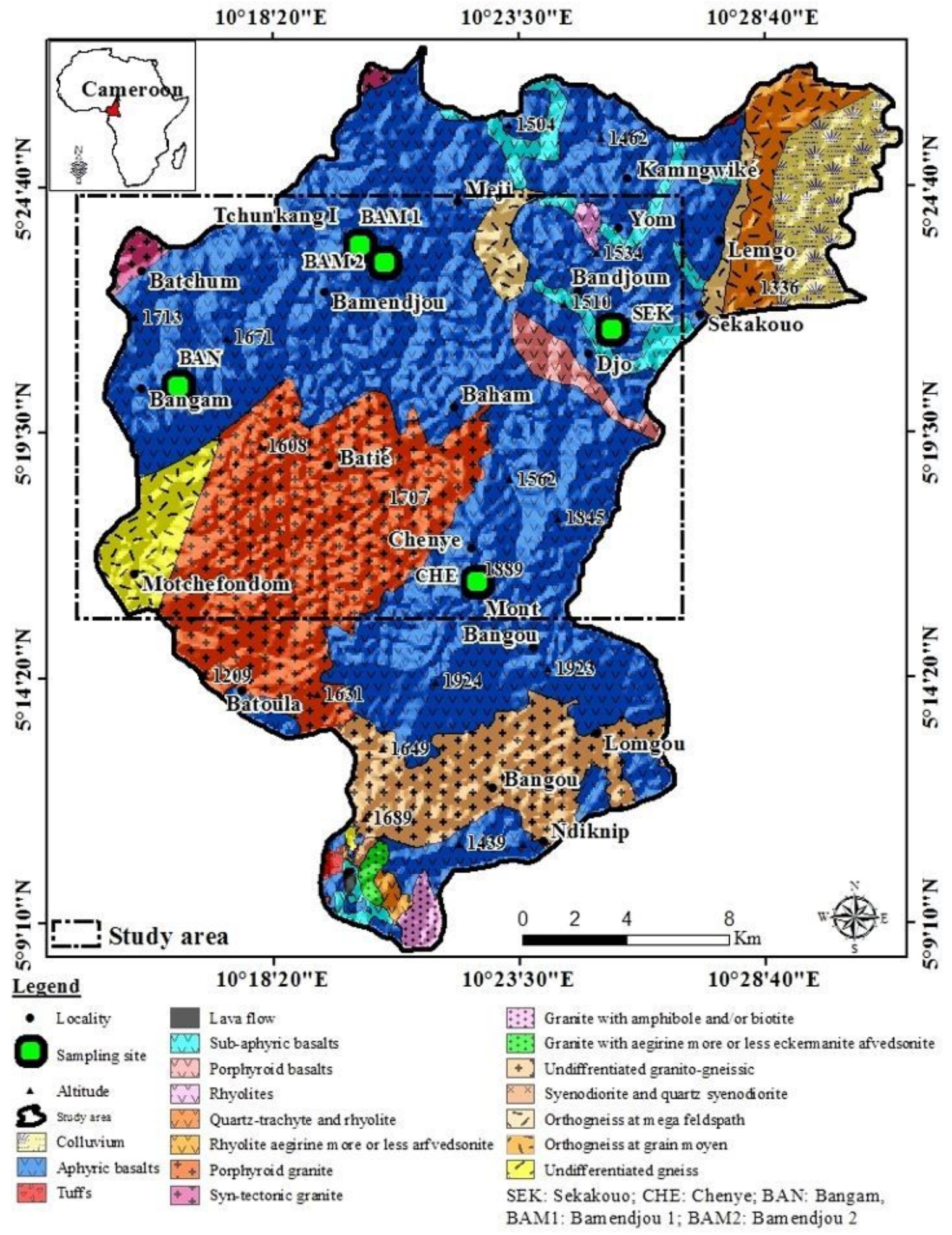

Figure 1

Geological map of the study area; modified from Fosso et al. (2005); Kuepou et al. (2006); Nono et al. (2009); Nkwekam et al. (2010) 


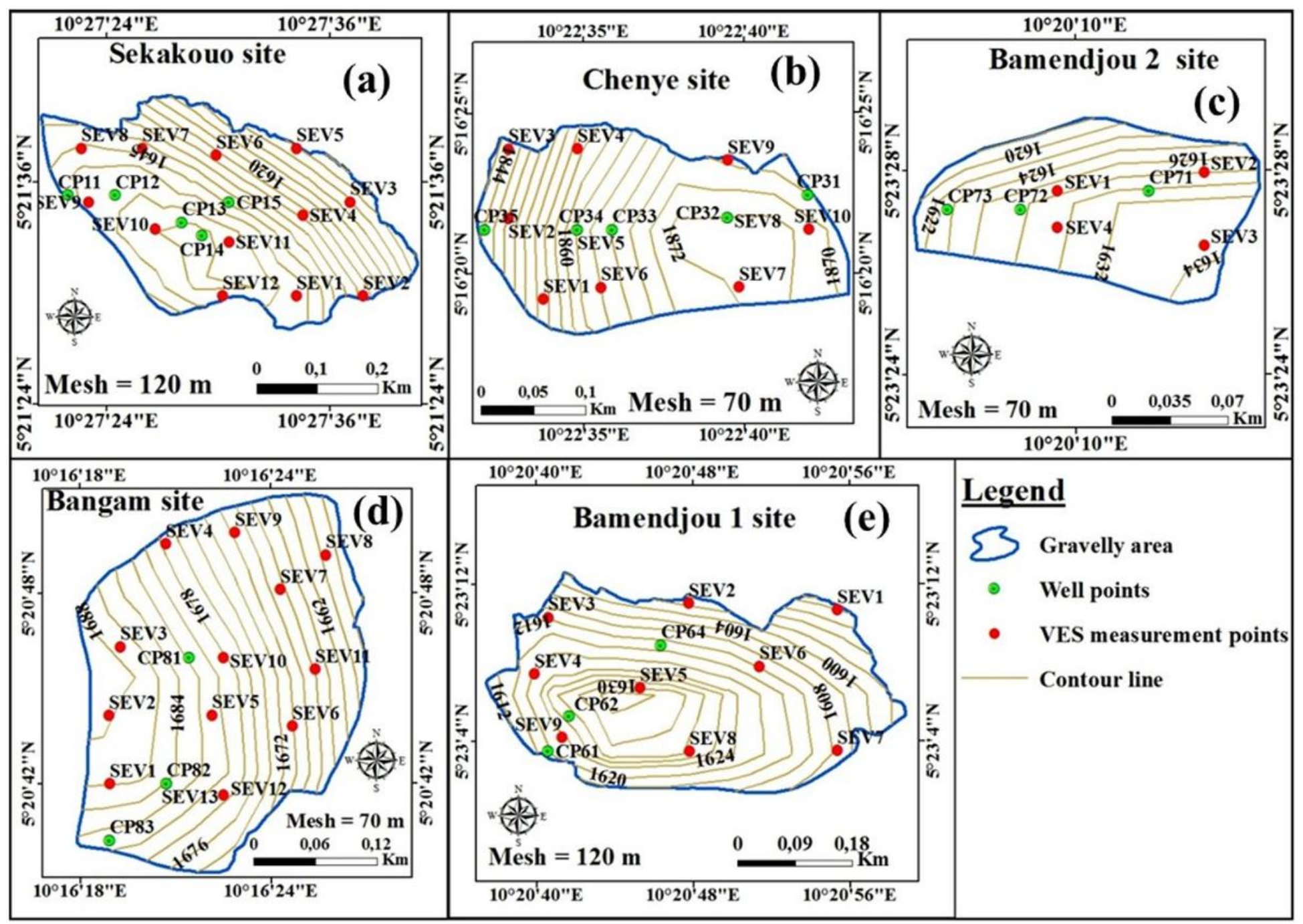

Figure 2

Sampling map of the studied sites; (a) Sekakouo; (b) Chenye; (c) Bamendjou 1; (d) Bamendjou 2 ; (e) Bangan. 


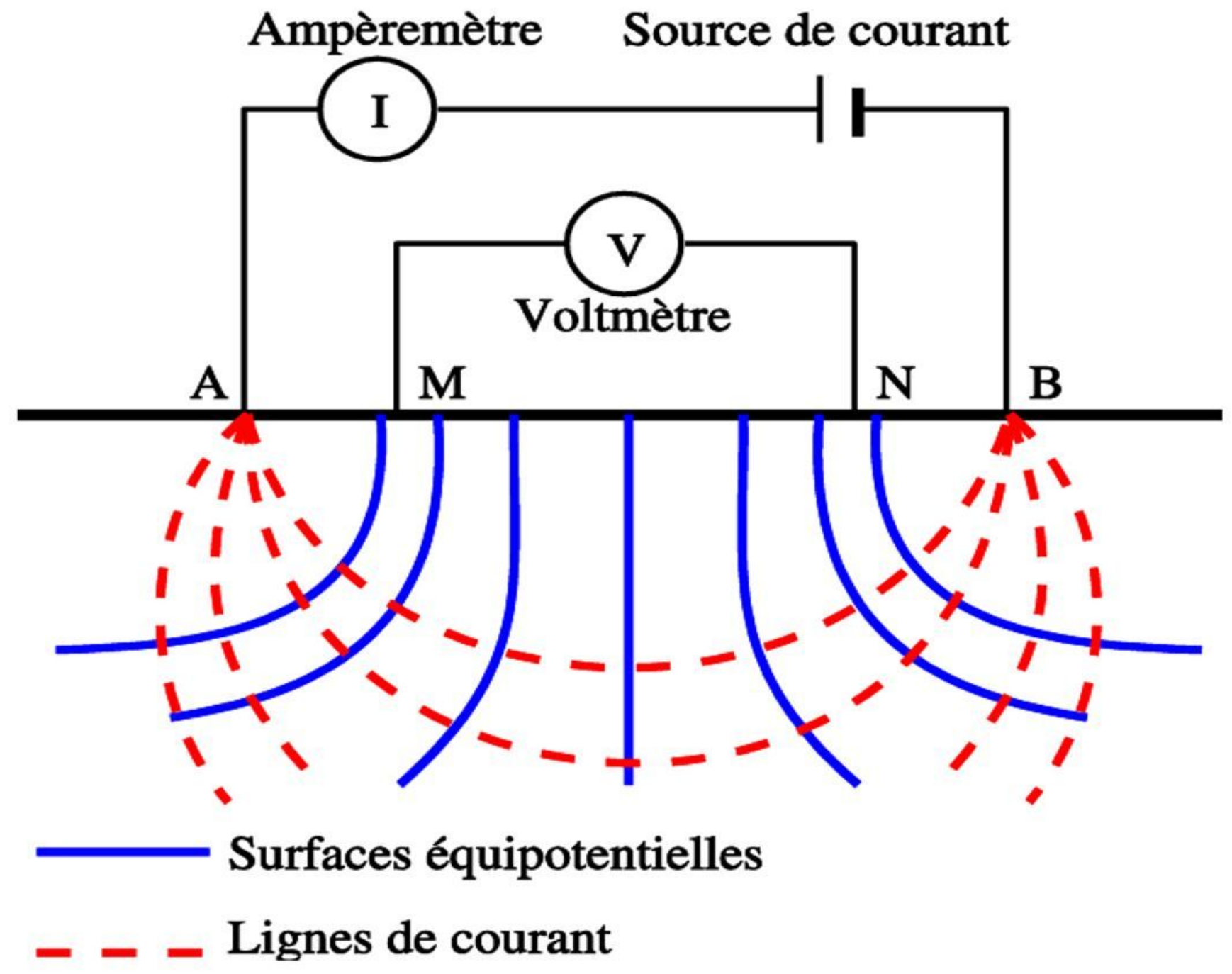

Figure 3

Schlumberger device (Fouchard and Mériaux, 2004)

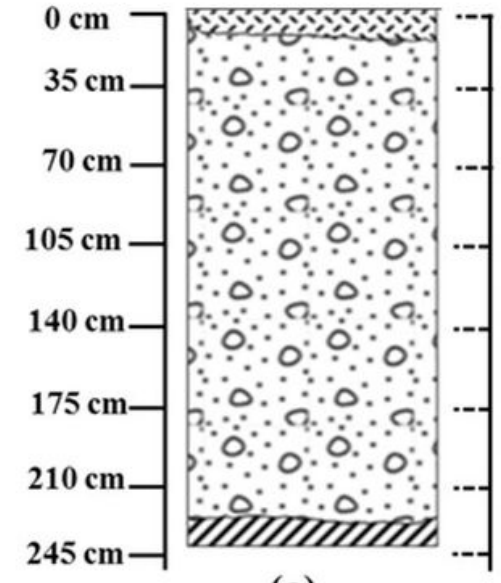

(a)

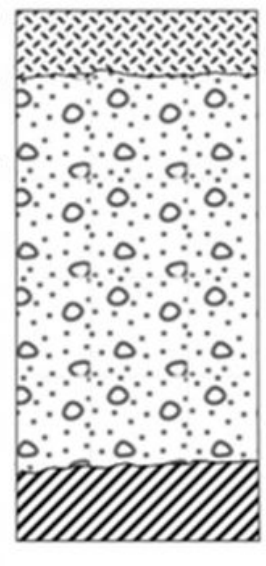

(b)

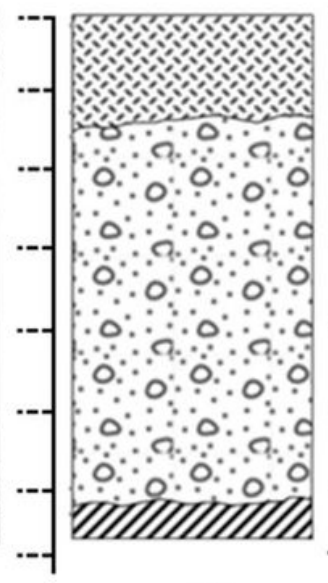

(c)

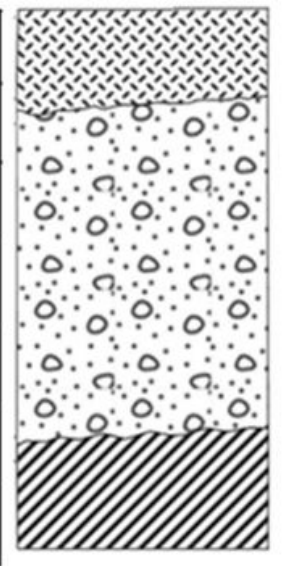

(d)

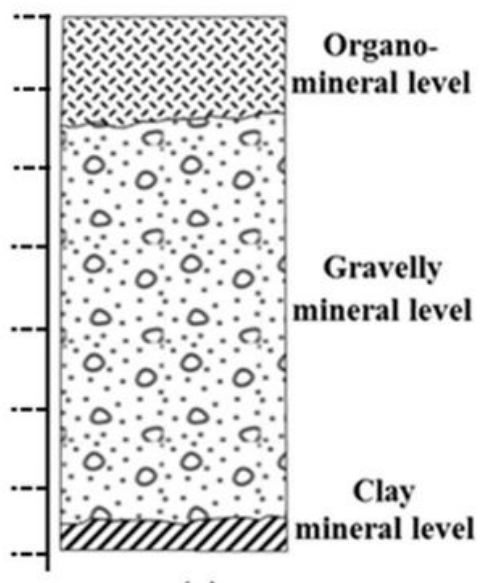

(e)

Figure 4 
Typical soil profile of the different site ; (a) Sekakouo site; (b) Chenye site; (c) Bamendjou 1 site; (d) Bamendjou 2 site and (e) Bangam site

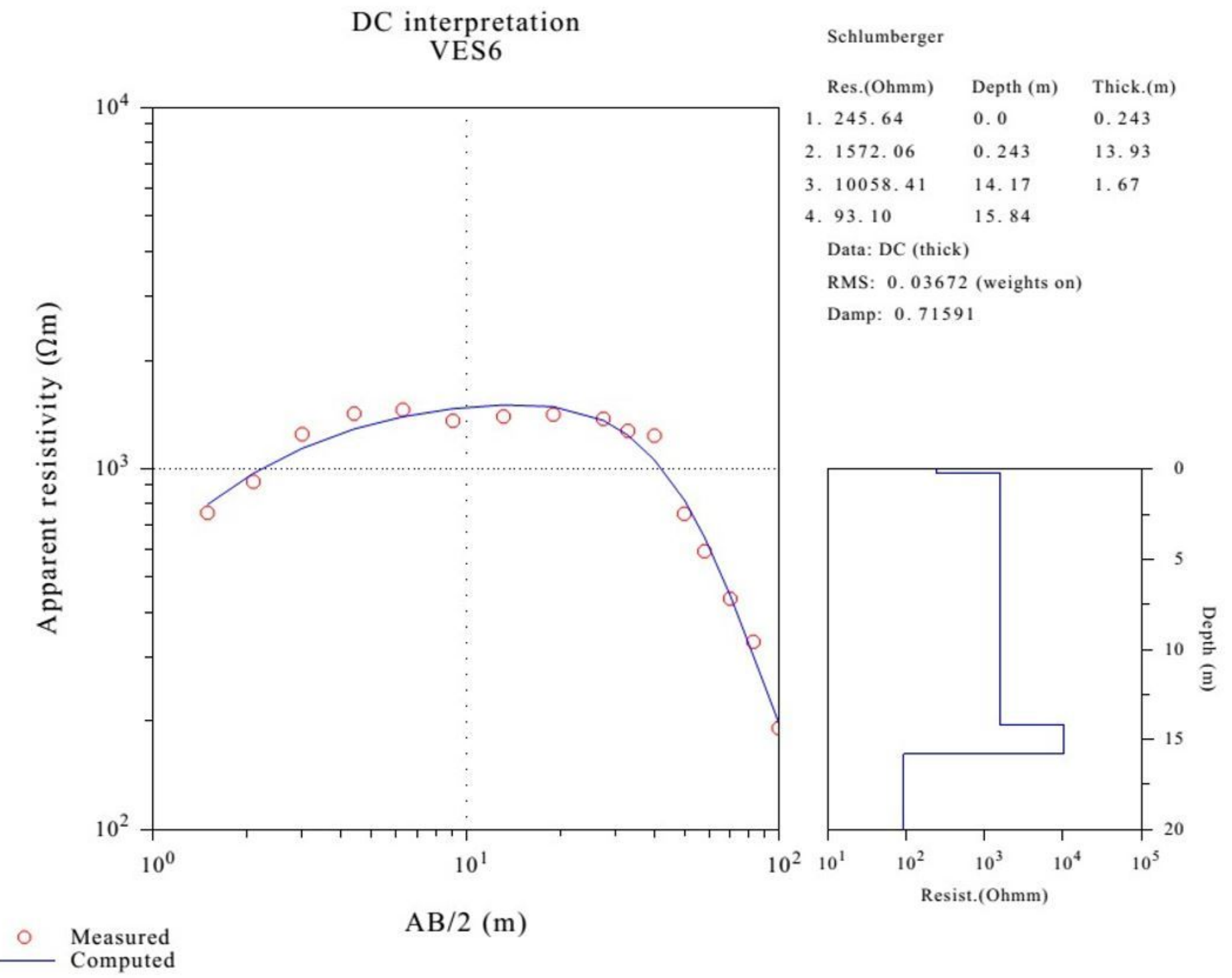

Figure 5

Typical geo-electric curve type $\mathrm{K}$ 


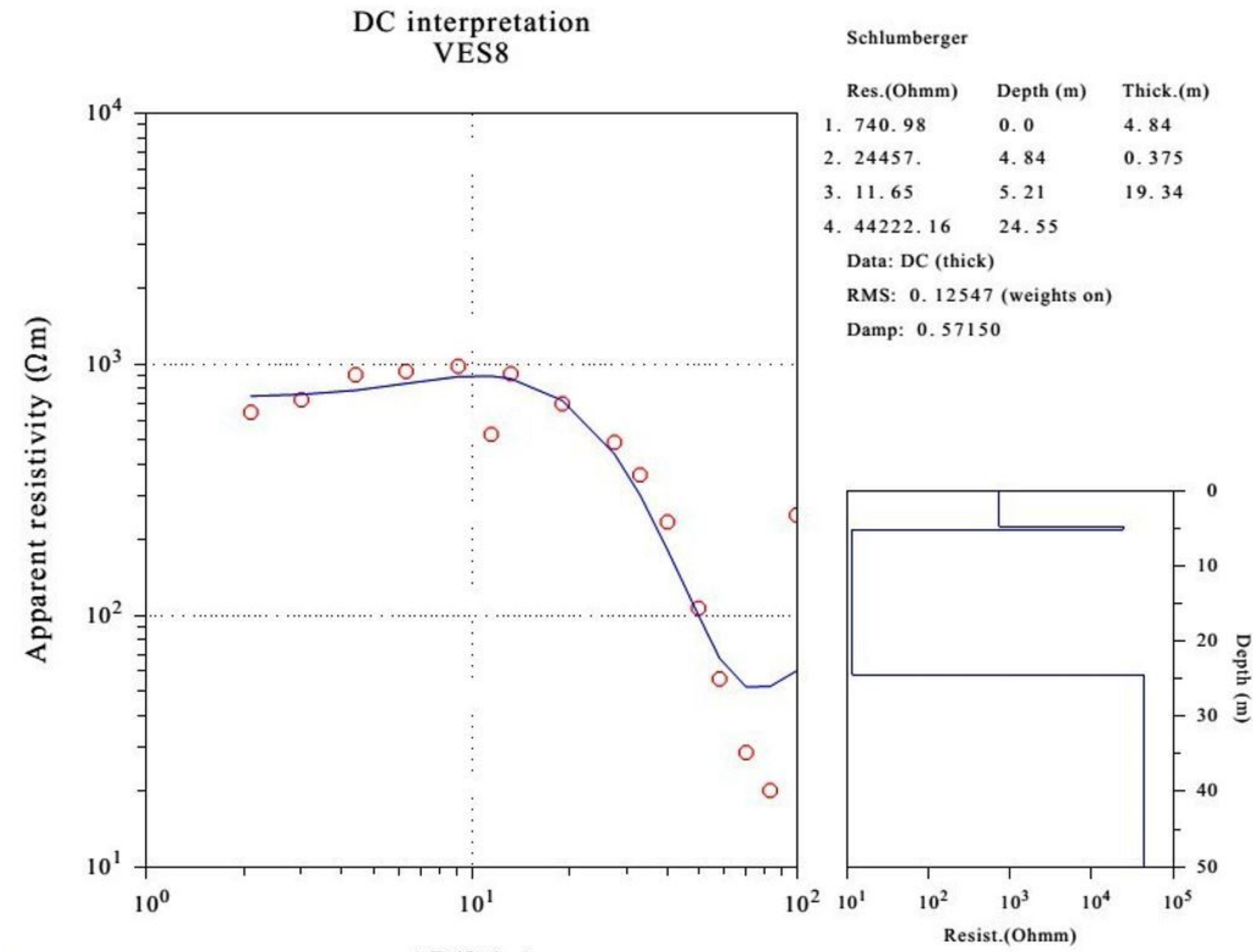

- Measured

$\mathrm{AB} / 2(\mathrm{~m})$

Computed

Figure 6

Typical geo-electric curve type $\mathrm{KH}$ 


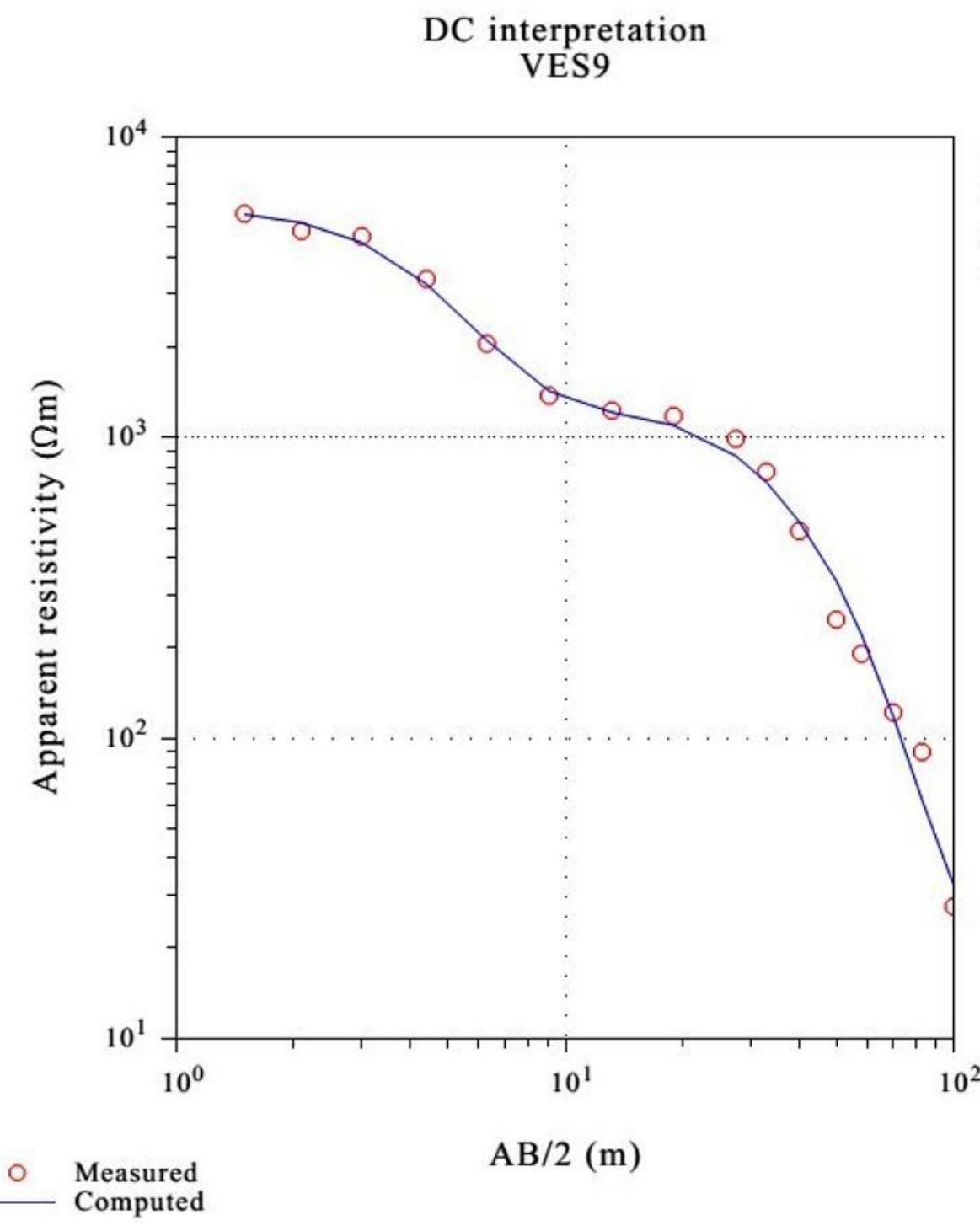

Schlumberger

Res.(Ohmm) Depth (m) Thick.(m)

$\begin{array}{lll}\text { 1. } 5774.15 & 0.0 & 2.31\end{array}$

$\begin{array}{lll}\text { 2. } 0.4508 & 2.31 & 0.001\end{array}$

$\begin{array}{lll}\text { 3. } 1372.31 & 2.31 & 15.44\end{array}$

4. $16.22 \quad 17.75$

Data: DC (thick)

RMS: 0.02643 (weights on)

Damp: 0.85722

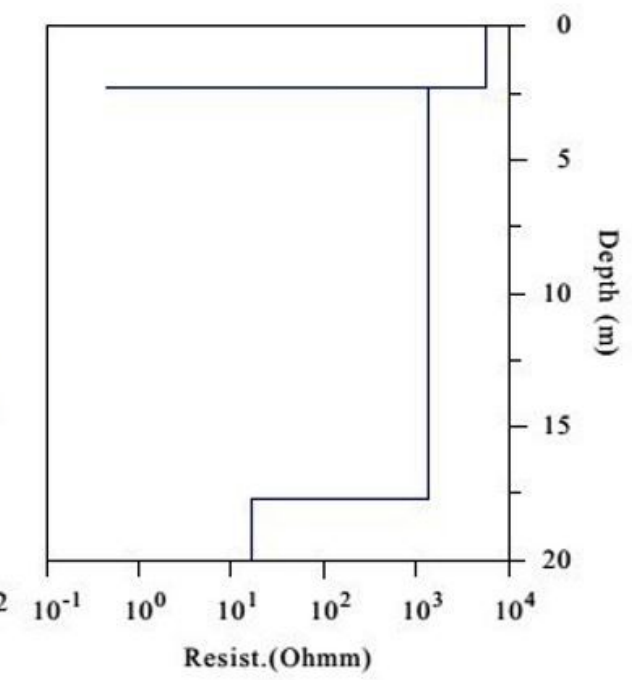

Figure 7

Typical geo-electric curve type HK 


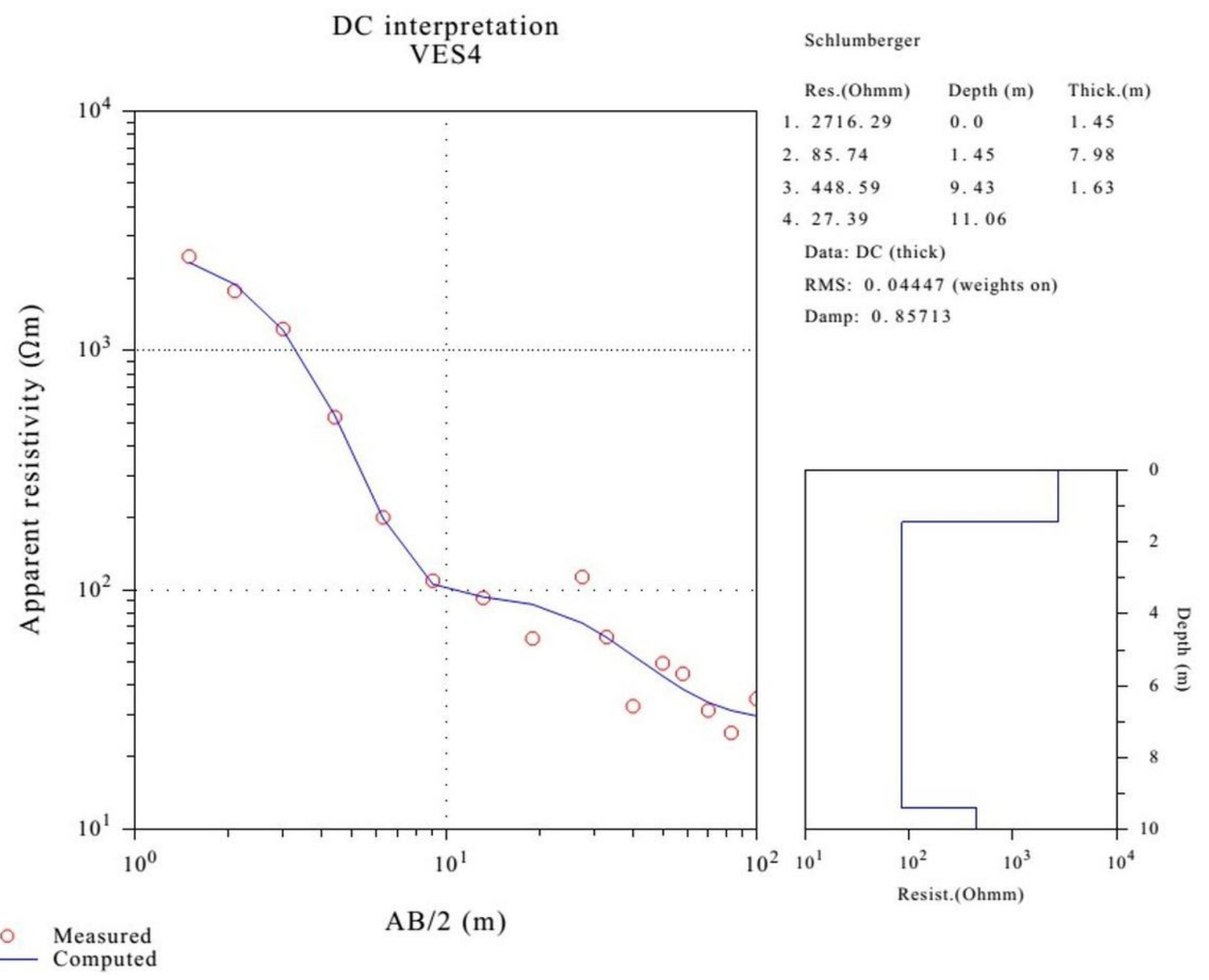

Figure 8

Typical geo-electric curve type $\mathrm{H}$ 


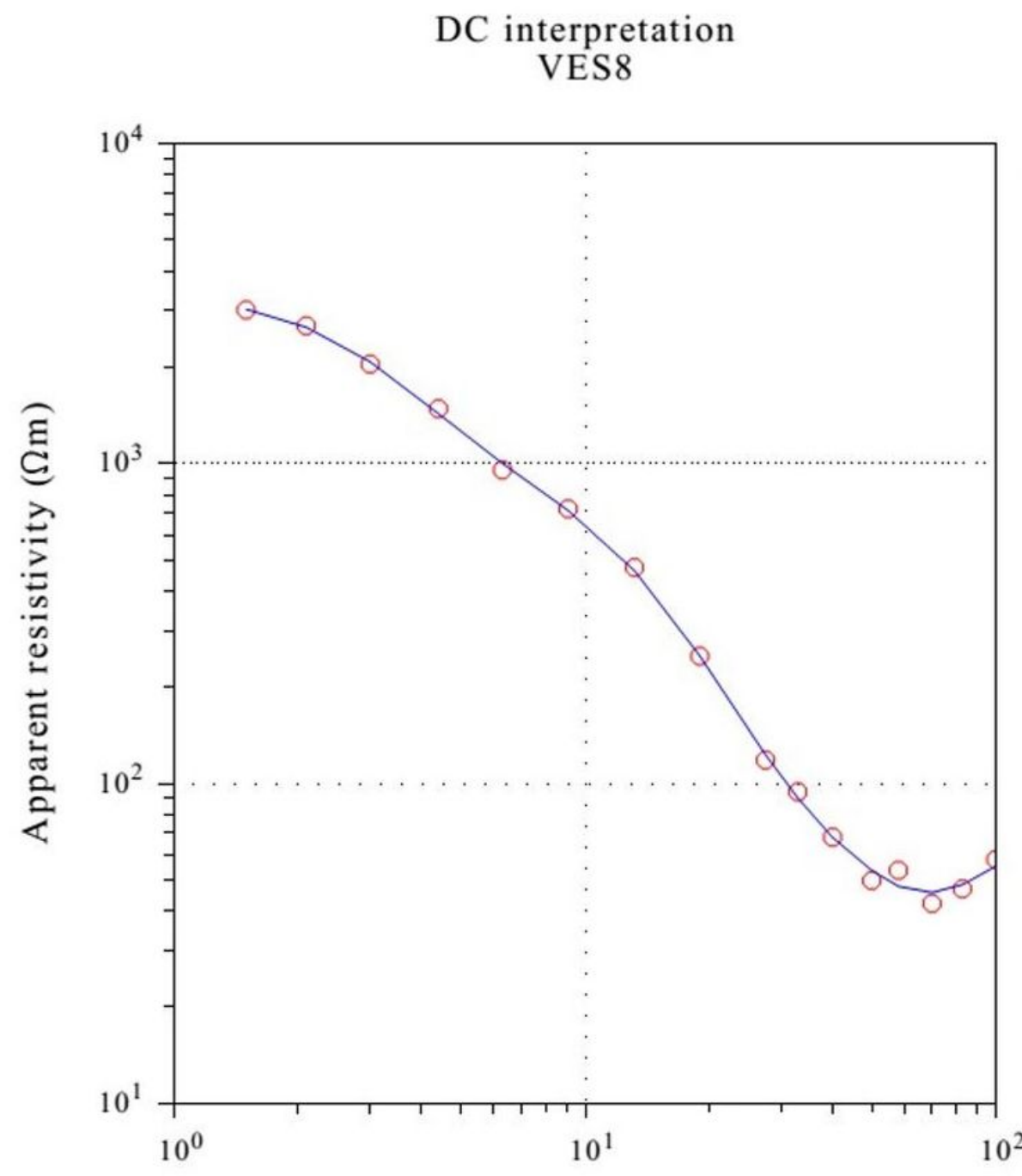

Schlumberger

Res.(Ohmm) Depth (m) Thick.(m)

$\begin{array}{lll}\text { 1. } 3356.55 & 0.0 & 1.44\end{array}$

2. $865.28 \quad 1.44 \quad 5.85$

$\begin{array}{lll}3.97 .27 & 7.29 & 17.97\end{array}$

$\begin{array}{lll}\text { 4. } 5.44 & 25.26 & 8.59\end{array}$

5. $1266.02 \quad 33.85$

Data: DC (thick)

RMS: 0.01111 (weights on)

Damp: 0.77856

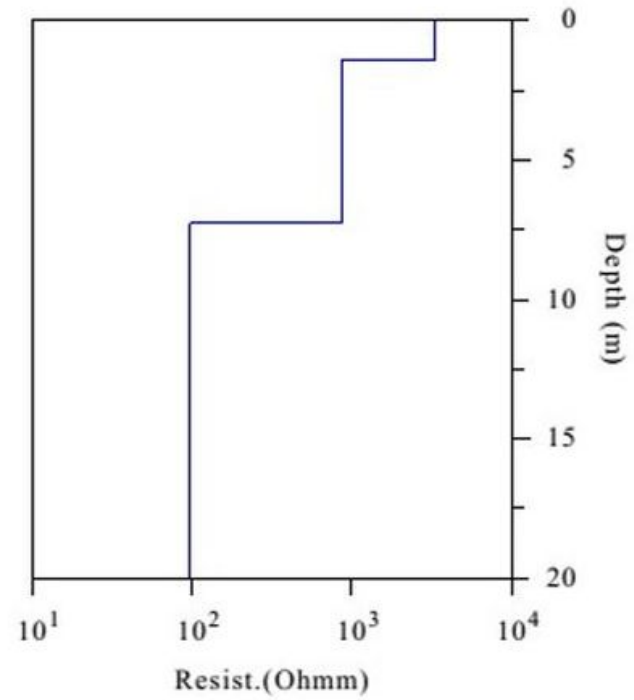

- Measured

$\mathrm{AB} / 2(\mathrm{~m})$

Resist.(Ohmm)

Figure 9

Typical geo-electric curve type QH 


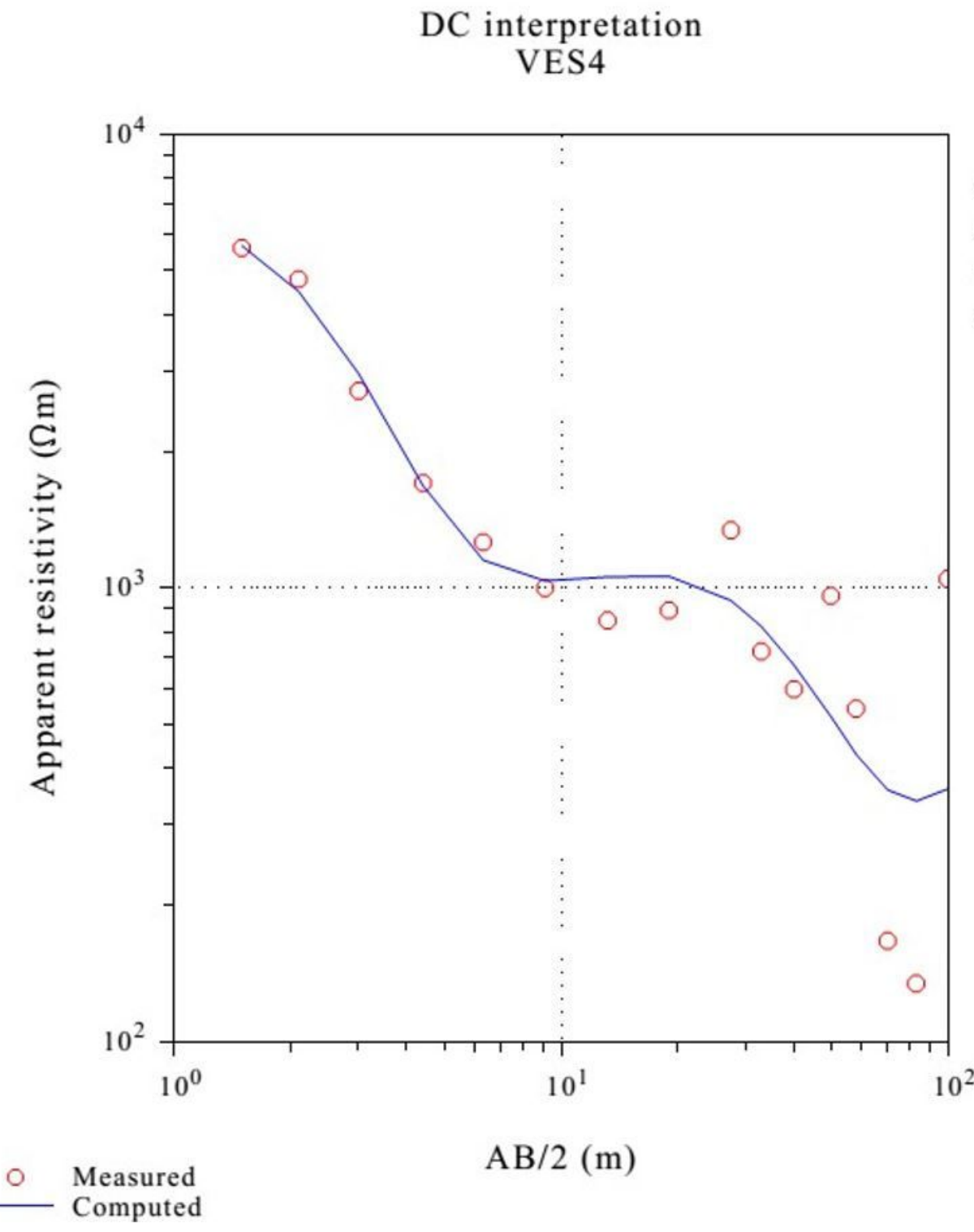

Schlumberger

Res.(Ohmm) Depth (m) Thick.(m)

$\begin{array}{lll}\text { 1. } 6821.21 & 0.0 & 1.23\end{array}$

$\begin{array}{lll}\text { 2. } 896.56 & 1.23 & 7.95\end{array}$

$\begin{array}{lll}3.10453 .81 & 9.18 & 1.53\end{array}$

$\begin{array}{lll}\text { 4. } 63.78 & 10.71 & 18.09\end{array}$

5. $685515.25 \quad 28.79$

Data: DC (thick)

RMS: 0.12101 (weights on)

Damp: 0.66670

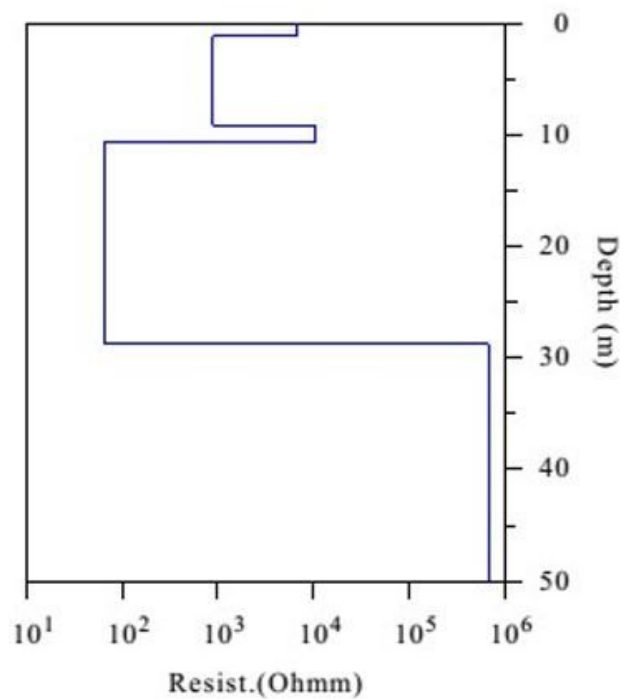

Figure 10

Typical geo-electric curve type HKH 


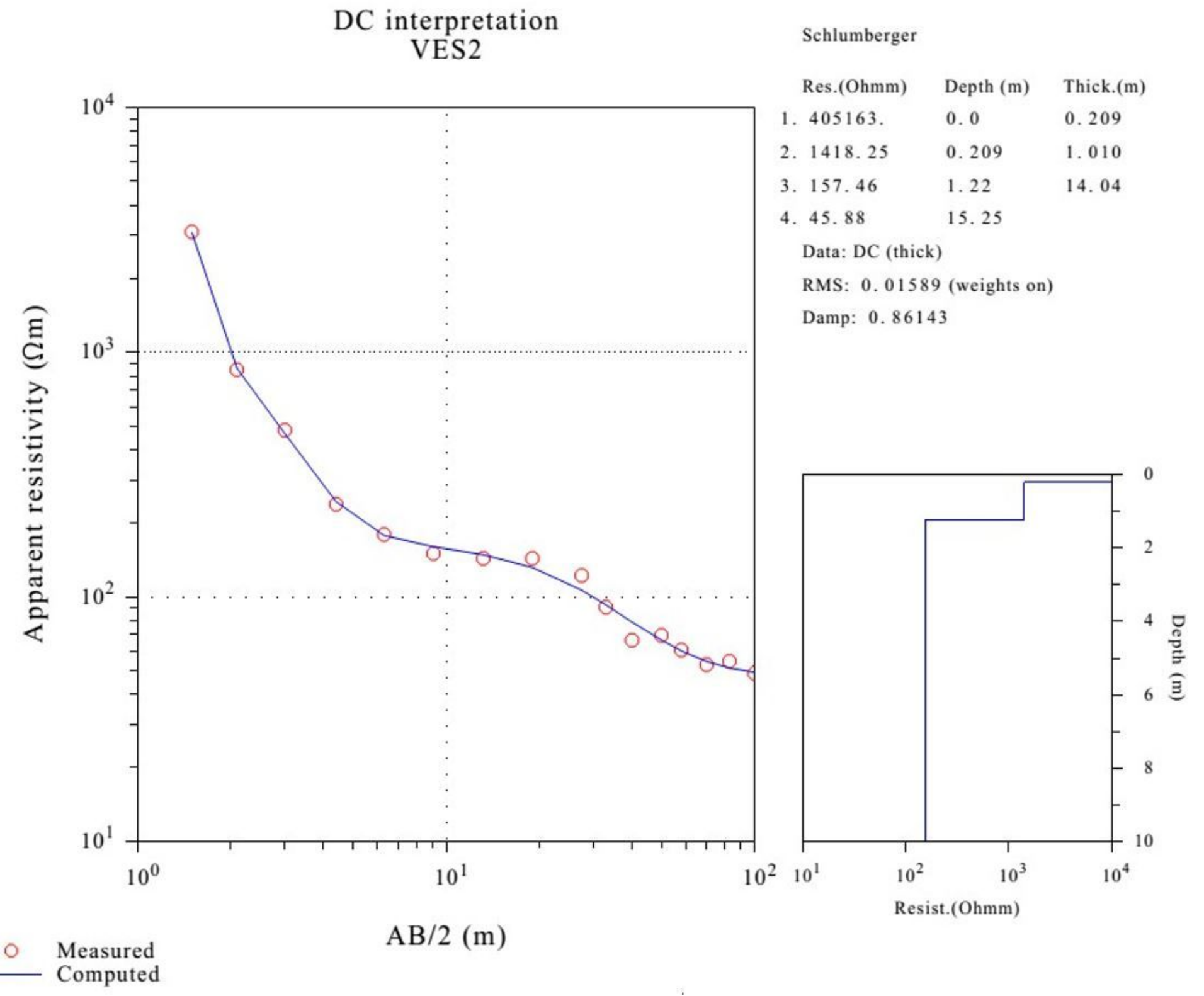

Figure 11

Typical geo-electric curve type Q 


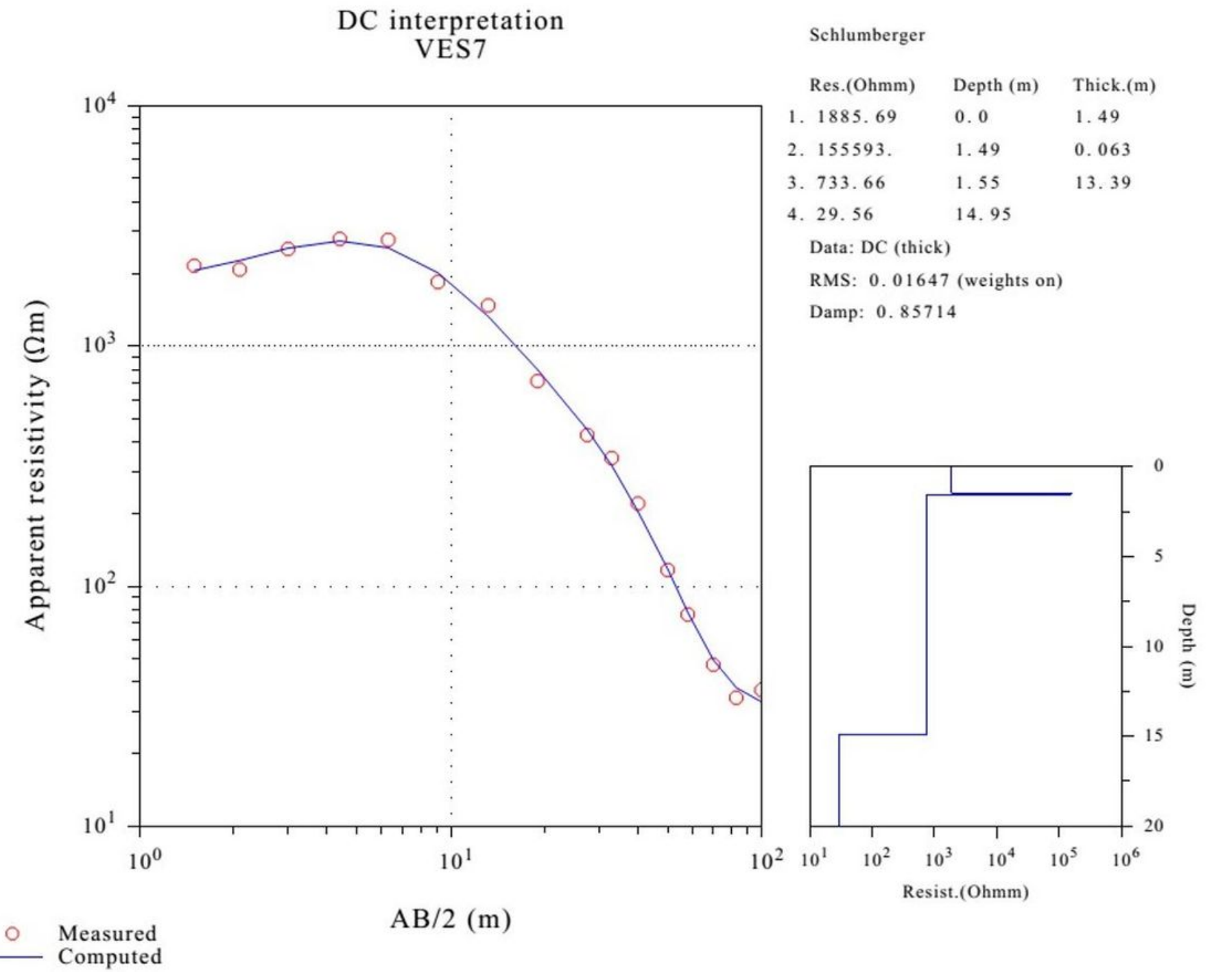

Figure 12

Typical geo-electric curve type KQ 

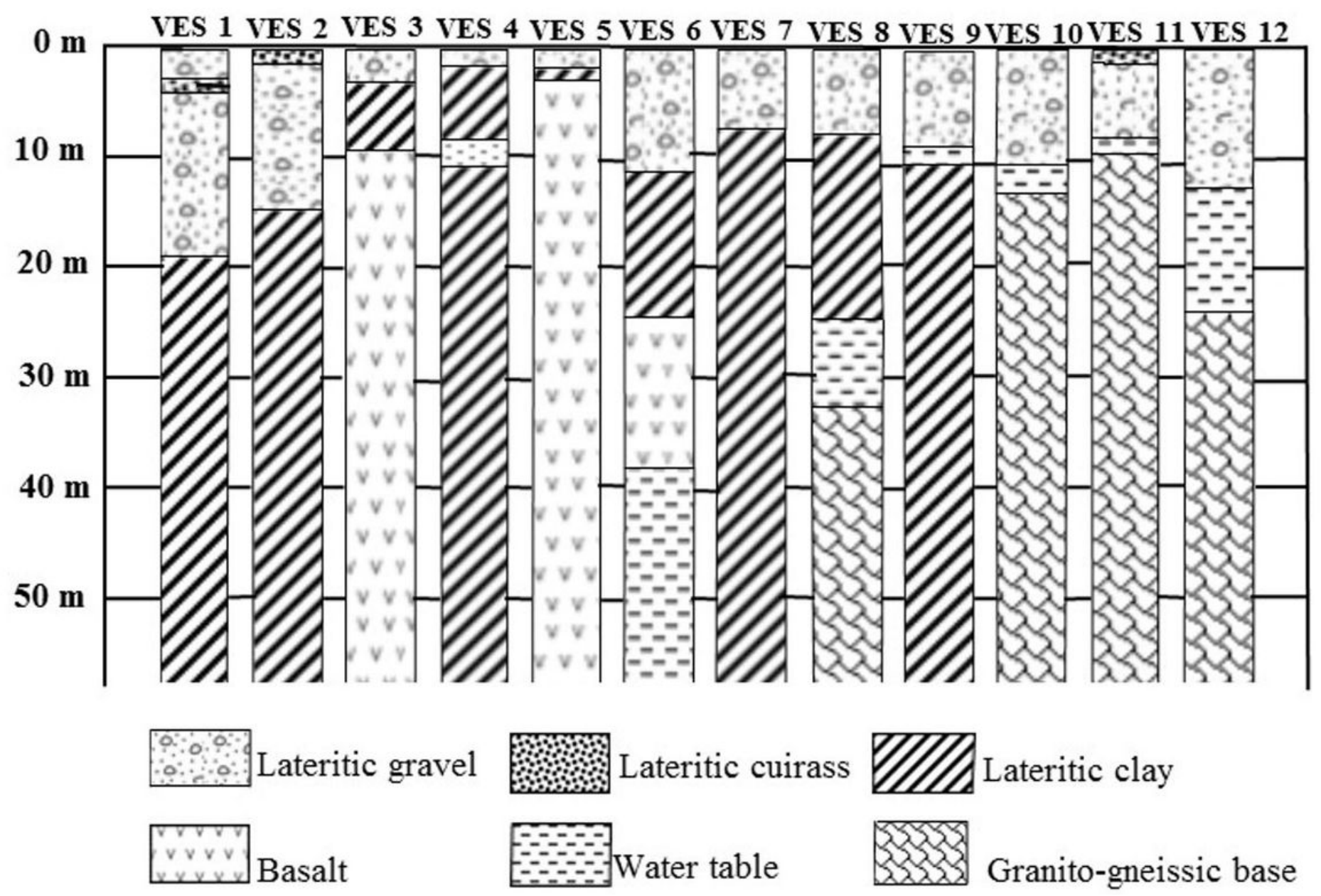

Figure 13

1-D lithology of the Sekakouo vertical electric drill holes 

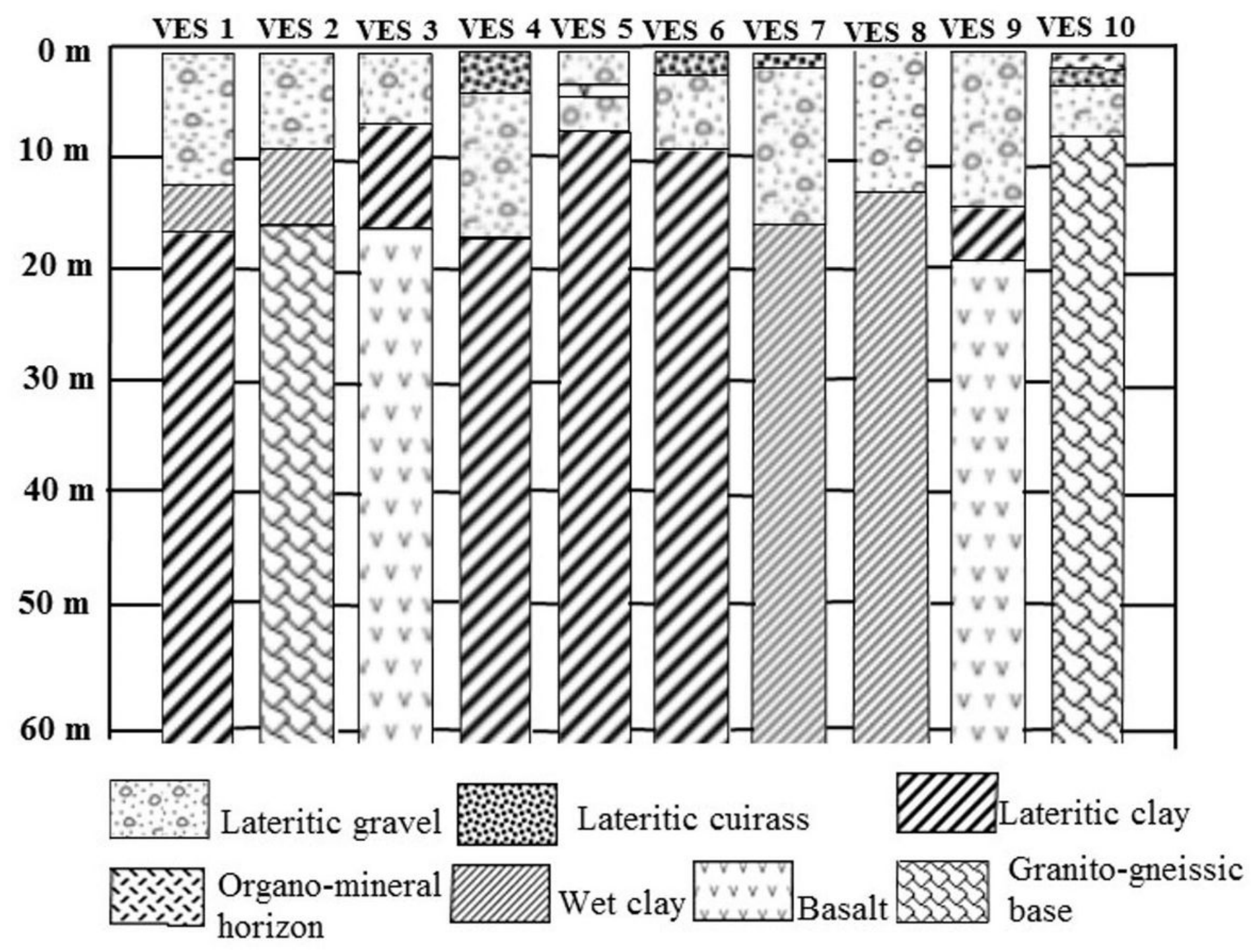

Figure 14

1-D lithology of the Chenye vertical electrical boreholes 


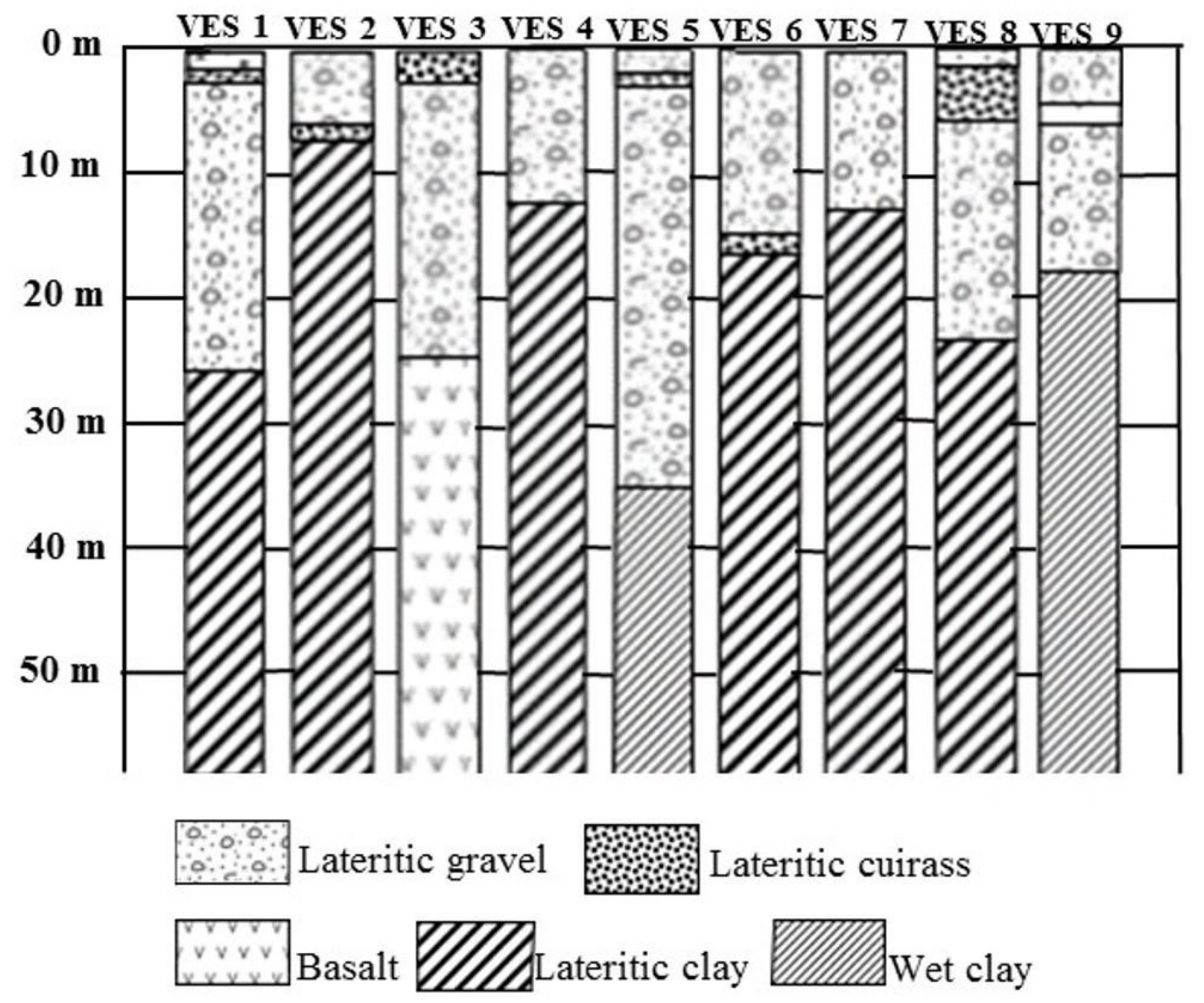

Figure 15

1-D lithology of the vertical electric soundings of Bamendjou 1 


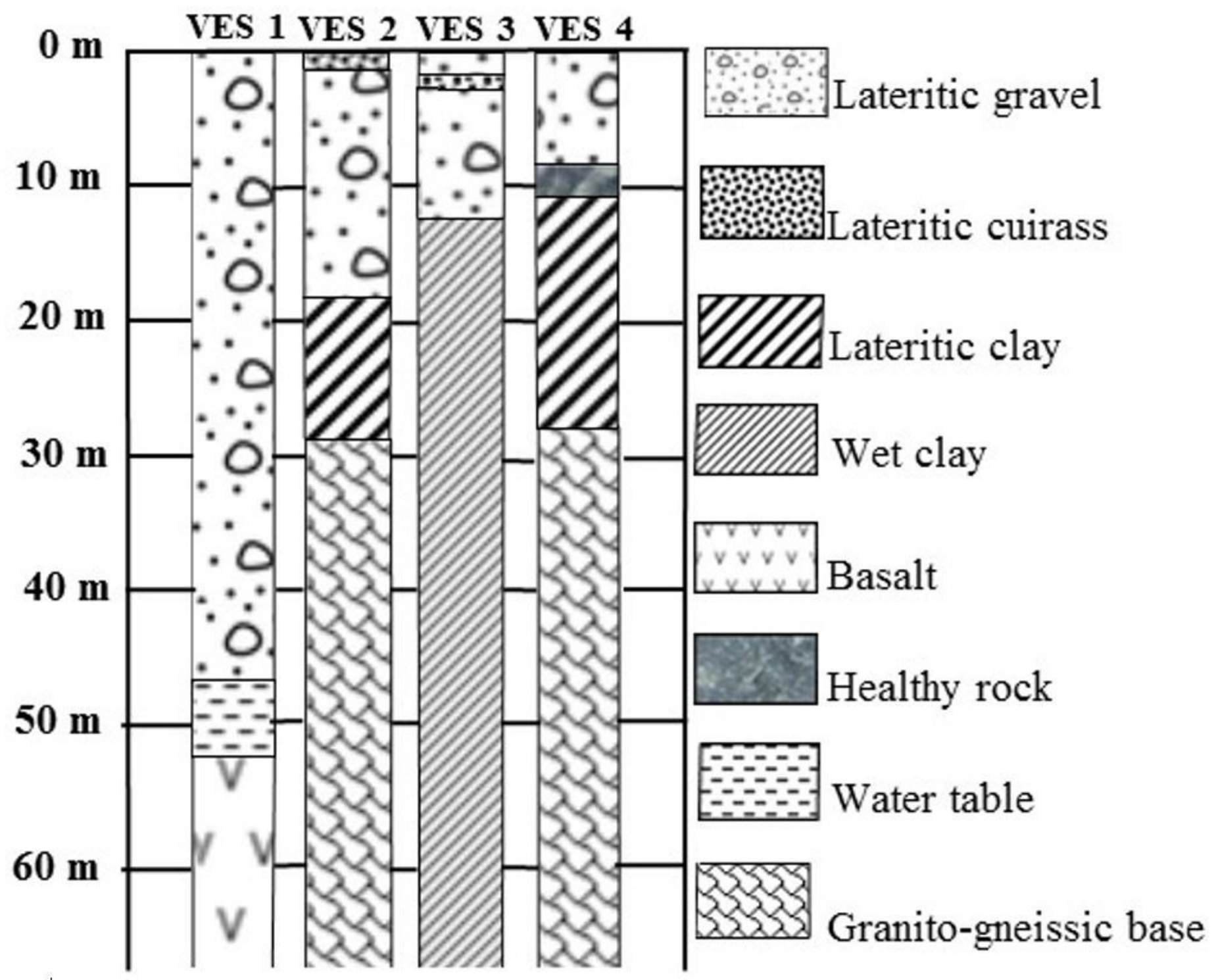

Figure 16

1-D lithology of the vertical electric drillings of Bamendjou 2 


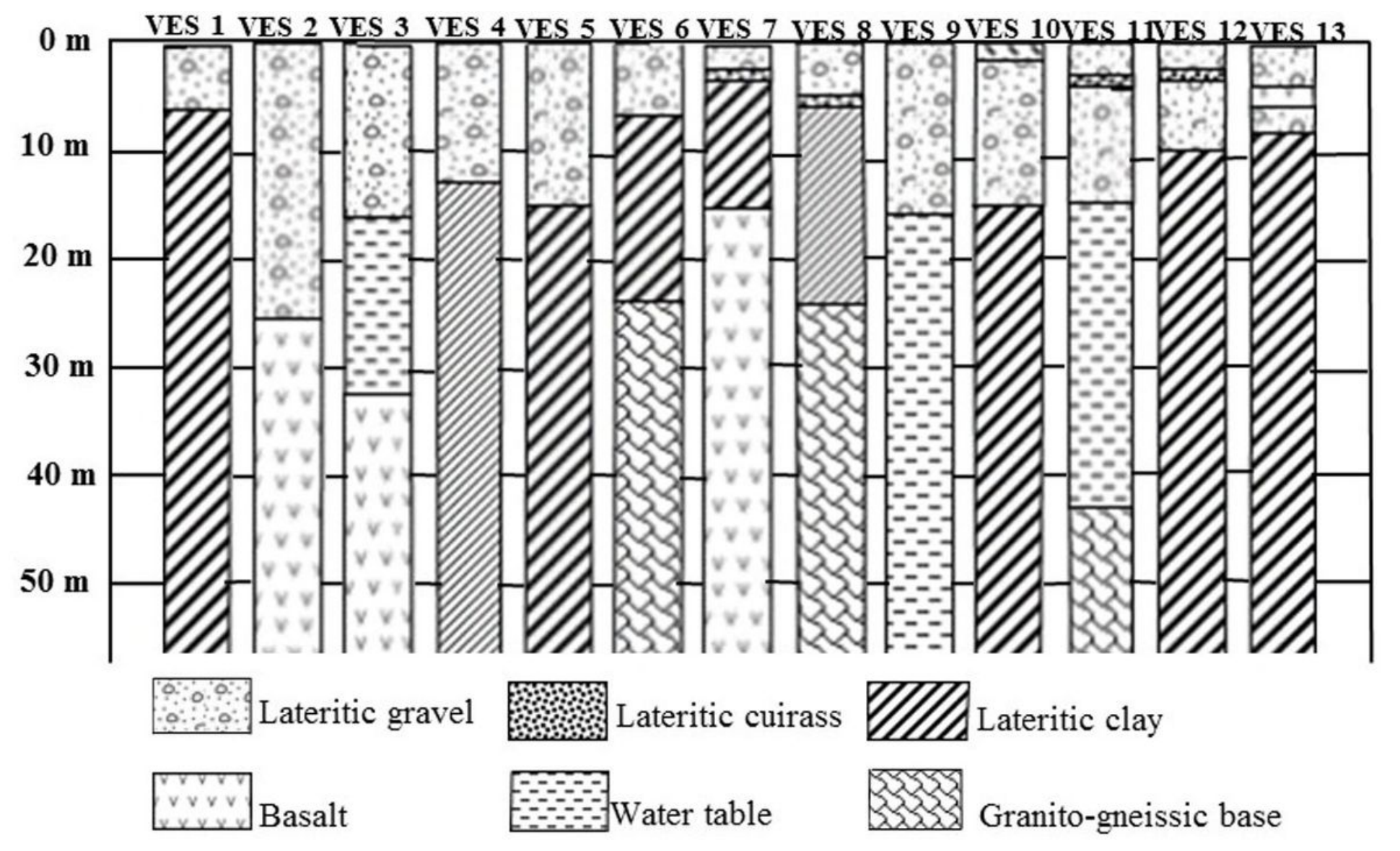

Figure 17

1-D lithology of the Bangam vertical electrical soundings. 


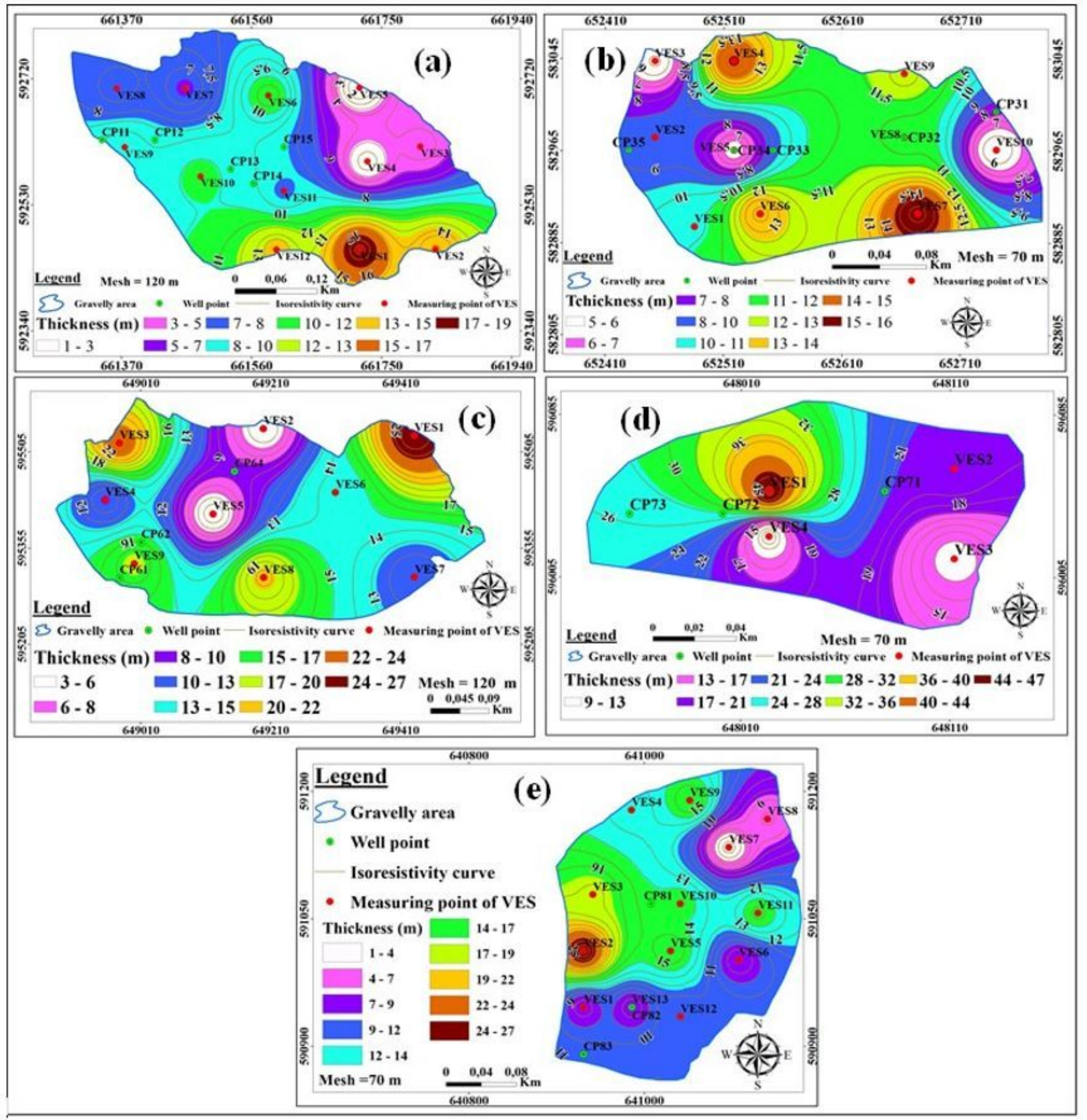

Figure 18

Thickness maps 